\title{
Investigating the sources and atmospheric processing of fine particles from Asia and the Northwestern United States measured during INTEX B
}

\author{
R. E. Peltier ${ }^{1, *}$, A. H. Hecobian ${ }^{1}$, R. J. Weber ${ }^{1}$, A. Stohl ${ }^{2}$, E. L. Atlas ${ }^{3}$, D. D. Riemer ${ }^{3}$, D. R. Blake ${ }^{4}$, E. Apel ${ }^{5}$, \\ T. Campos ${ }^{5}$, and T. Karl ${ }^{5}$ \\ ${ }^{1}$ Georgia Institute of Technology, School of Earth and Atmospheric Science, Atlanta, GA 30332-0340, USA \\ ${ }^{2}$ Norwegian Institute for Air Research, 2027 Kjeller, Norway \\ ${ }^{3}$ University of Miami, Rosenstiel School of Marine and Atmospheric Science, Miami, FL 33149-1098, USA \\ ${ }^{4}$ Department of Chemistry. University of California Irvine, Irvine, CA, 92697-2025, USA \\ ${ }^{5}$ National Center for Atmospheric Research, Atmospheric Chemistry Division, Boulder, CO 80307, USA \\ * now at: Department of Environmental Medicine, NYU School of Medicine, Tuxedo, NY 10987, USA
}

Received: 16 November 2007 - Published in Atmos. Chem. Phys. Discuss.: 29 November 2007

Revised: 29 February 2008 - Accepted: 29 February 2008 - Published: 27 March 2008

\begin{abstract}
During the National Aeronautics and Space Administration (NASA) Intercontinental Chemical Transport Experiment, Phase B (INTEX-B), in the spring of 2006, airborne measurements were made in the United States Pacific Northwest of the major inorganic ions and the water-soluble organic carbon (WSOC) of submicron $\left(\mathrm{PM}_{1.0}\right)$ aerosol. An atmospheric trajectory (HYSPLIT) and a Lagrangian particle dispersion model (Flexpart) quantifying source contributions for carbon monoxide $(\mathrm{CO})$ were used to segregate air masses into those of primarily Asian influence ( $>75 \%$ Asian $\mathrm{CO}$ ) or North American influence ( $>75 \%$ North American CO). Of the measured compounds, fine particle mass mostly consisted of water-soluble organic carbon and sulfate, with median sulfate and WSOC concentrations in two to four times higher, respectively, in North American air masses versus transported Asian air masses. The fraction of WSOC to sulfate in transported Asian air masses was significantly lower than one at altitudes above $3 \mathrm{~km}$ due to depleted organic aerosol, opposite to what has been observed closer to Asia and in the northeastern United States, where organic components were at higher concentrations than sulfate in the free troposphere. The observations could be explained by loss of sulfate and organic aerosol by precipitation scavenging, with reformation of mainly sulfate during advection from Asia to North America. In contrast to free tropospheric measurements, for all air masses below approximately $2 \mathrm{~km}$ altitude median WSOC-sulfate ratios were consistently between
\end{abstract}

Correspondence to: R. J. Weber (rweber@eas.gatech.edu) one and two. WSOC sources were investigated by multivariate linear regression analyses of WSOC and volatile organic compounds (VOCs). In Asian air masses, of the WSOC variability that could be explained (49\%), most was related to fossil fuel combustion VOCs, compared to North American air masses, where $75 \%$ of the WSOC variability was explained through a nearly equal combination of fossil fuel combustion and biogenic VOCs. Distinct WSOC plumes encountered during the experiment were also studied. A plume observed near the California Central Valley at $0.6 \mathrm{~km}$ altitude was related to both fossil fuel combustion and biogenic VOCs. Another Central Valley plume observed over Nevada at 3 to $5 \mathrm{~km}$, in a region of cloud detrainment, was mostly related to biogenic VOCs.

\section{Introduction}

Expanding arid regions and biomass burning in Asia, along with the rapid industrialization of China, has led to emissions from the Asian continent that are a significant global source of tropospheric aerosols (Streets and Waldhoff, 2000; Streets et al., 2003; Streets, 2007). Numerous studies have investigated the long range transport of Asian mineral dust and pollution (Jaffe et al., 1999; Huebert et al., 2003; Bertschi and Jaffe, 2005; Jaffe et al., 2005), including extensive airborne measurements made near the Asian coast during the ACEAsia (Huebert et al., 2003) and TRACE-P (Jacob et al., 2003) research campaigns in the spring of 2001. Other studies have examined transported Asian aerosol as they approached the

Published by Copernicus Publications on behalf of the European Geosciences Union. 
North American continent (Park et al., 2003; de Gouw et al., 2004; Heald et al., 2005; Jaffe et al., 2005).

Airborne measurements during TRACE-P and ACE-Asia of fine particle chemical composition identified both relatively pure plumes and mixed plumes of mineral dust, biomass burning, and anthropogenic emissions. Biomass burning plumes consisted of fine particle ammonium, nitrate, water-soluble potassium, as well as organic carbon and elemental carbon (Ma et al., 2003). Anthropogenic plumes were comprised mainly of sulfate and nitrate, with associated ammonium (Lee et al., 2003), and carbonaceous material that was mainly organic carbon (OC) (Maria et al., 2003; Huebert et al., 2004a). From soundings conducted off the coast of Asia, sulfate concentrations on average dropped from $\sim 4 \mu \mathrm{g} \mathrm{sm}^{-3}$ near the surface to less than $1 \mu \mathrm{g} \mathrm{sm}^{-3}$ in the free troposphere. Elemental carbon (EC) had a similarly shaped profile (see Heald et al., 2005 and references therein). In contrast, OC concentrations ranged from on average $\sim 4$ to $5 \mu \mathrm{gC} \mathrm{sm}^{-3}$ and were fairly uniform from the surface up to the upper measurement range of 6 to $7 \mathrm{~km}$ above sea level (a.s.l.). This resulted in mass ratios of organic carbon to sulfate of near one below $\sim 2 \mathrm{~km}$ a.s.l., but ratios of 3 to 4 in the 3 to $\sim 6 \mathrm{~km}$ a.s.l. altitude range. Similar types of aerosol chemical components were observed in the anthropogenic-influenced Northeastern United States measured during ICARTT (Peltier et al., 2007a), and a similar altitude profile of organic carbon to sulfate was observed. These and other studies have demonstrated the importance of $\mathrm{OC}$ in the free troposphere.

Numerical simulations aimed at understanding the sources and atmospheric processing of sulfate and organic carbon in these two study domains demonstrated limitations with current understandings of $\mathrm{OC}$ sources and processing (Heald et al., 2005, 2006). For the ACE-Asia study, sulfate and EC were well predicted by GEOS-Chem, but OC was significantly under predicted, indicating unknown and unaccounted for OC sources (Heald et al., 2005). For the eastern United States ICARTT dataset, the average OC mass (actually, the mass of water-soluble OC) was predicted fairly well by GEOS-Chem, but individual observations were poorly correlated (Heald et al., 2006), suggesting a poor understanding of atmospheric formation of WSOC.

A number of other recent studies have also demonstrated a general lack of understanding of OC sources and processing in regions impacted by urban anthropogenic emissions (de Gouw et al., 2005; Johnson et al., 2006; Volkamer et al., 2006; de Gouw et al., 2007). These studies indicated there is a significant yet unknown anthropogenic route for secondary organic aerosol production. OC is a substantial fraction of fine particle aerosol mass and a poor understanding of its sources and processing hinders development of strategies to improve air quality and assess its role in global climate. Understanding $\mathrm{OC}$ has been impeded by its chemical complexity, in part due to its many sources, ranging from biogenic to anthropogenic emissions that produce both primary or sec- ondary particles (Rogge et al., 1993; Jacobson et al., 2000; Turpin et al., 2000; Seinfeld and Pankow, 2003).

A subset of $\mathrm{OC}$ is the fraction that is water-soluble. Socalled water-soluble organic carbon (WSOC) is of interest since it may have unique and important health effects and indirect impacts on the planetary radiation balance. WSOC has two main sources: biomass burning and secondary organic aerosol formation (Huang et al., 2006; Sullivan et al., 2006; Huang and Yu, 2007; Weber et al., 2007). WSOC comprises typically $30-80 \%(\mathrm{gC} / \mathrm{gC})$ of $\mathrm{OC}$, with lowest ratios generally recorded near sources with large primary emissions and highest ratios in aged air masses (Zappoli et al., 1999; Decesari et al., 2001; Jaffrezo et al., 2005). Single particle composition studies show that most aged fine particles are internal mixtures of sulfate and organic compounds (Murphy et al., 2006).

In the spring of 2006, airborne measurements were made of the major inorganic ions and the water-soluble organic carbon (WSOC) of submicron $\left(\mathrm{PM}_{1.0}\right)$ aerosol with the goal to study the impact of transported Asian emissions on the Northwestern United States (Singh et al., 2008 ${ }^{1}$ ). This research was part of the National Aeronautical Space Administration (NASA) Intercontinental Chemical Transport Experiment, Phase B (INTEX-B). The National Center for Atmospheric Research (NCAR) C130 research aircraft participated in this study, and was based at Paine Field in Everett, Washington, $\left(47.91^{\circ} \mathrm{N},-122.28^{\circ}\right)$. The $\mathrm{C} 130$ conducted 10 research flights (plus two transit flights) that intercepted emissions mainly from Asia as they approached the North American continent. Research flights were conducted from 21 April 2006 to 15 May 2006. Altitude range of the aircraft extended from $\sim 0.1 \mathrm{~km}$ to $\sim 7.3 \mathrm{~km}$ a.s.l., with a nominal flight range of $\sim 1300 \mathrm{~km}$ from base. Instruments deployed on the NSF C130 pertinent to this study are discussed in the following section.

\section{Methods}

Fine particle bulk chemical composition was measured online from the C130 with two automated systems, each involving a Particle-Into-Liquid Sampler (PILS). The PILS quantitatively transfers ambient aerosol into a liquid stream that can then be analyzed for specific aerosol chemical components. One PILS was coupled to two Metrohm ${ }^{\circledR}$ Ion Chromatographs (Model 761, Houston, TX), while the second was coupled to a Sievers Total Organic Carbon analyzer (GE Water Systems, Model 800T, Boulder, CO). The first instrument package is referred to as PILS-IC (ion chromatograph), and the second as PILS-TOC (Total Organic Carbon analyzer). Detailed descriptions of these instruments have been

\footnotetext{
${ }^{1}$ Singh, H. B., Brune, W. H., Crawford, J. H., Jacob, D. J., Russell, P. B., et al.: An Overview of the INTEX-B Campaign: Transport and Transformation of Pollutants over the Pacific and the Gulf of Mexico, Atmos. Chem. Phys. Discuss., in preparation, 2008.
} 
published (Weber et al., 2001; Orsini et al., 2003; Sullivan et al., 2006; Sullivan and Weber, 2006; Peltier et al., 2007a) Aerosol was sampled with a constant flow nominally isokinetic inlet designed and constructed by Dunlea et al. (2008) ${ }^{2}$ following the design of Clarke and coworkers (Huebert et al., 2004b), and was located on the underside of the aircraft roughly three quarters of the way aft in the free air stream. This inlet was shared with an Aerosol Mass Spectrometer that extracted a portion of flow upstream of the PILS from the centerline of the 1 inch OD sample transport tube. Aerosol was then passed through a non-rotating multi-orifice impactor (Marple et al., 1991) that had a nominal particle cut size of $1.0 \mu \mathrm{m}$ at 1 atmosphere. Sample temperature, relative humidity, and pressure were measured, and the sample then divided equally using a "Y" to each PILS operating at $\sim 15 \mathrm{~L} / \mathrm{min}$.

\section{$2.1 \quad$ PILS-IC}

The PILS-IC was operating using a 2.45 min cation and $75 \mathrm{~s}$ anion chromatographic separation. For cation separation, a "Cation 1-2" resin column (Metrohm-Peak, Houston, TX) was used. Over a $90 \mathrm{~s}$ period, PILS effluent was pumped through a $150 \mu 1$ sample loop for injection onto the column. Eluent with concentrations of $8.5 \mathrm{mM} \mathrm{L}$-tartaric acid and $4.1 \mathrm{mM}$ dipicolinic acid was used to isocratically separate cationic components: sodium, ammonium, calcium, potassium, and magnesium. For this setup, cation limits of detection (LOD) for each species were $0.1 \mu \mathrm{g} \mathrm{sm}^{-3}$, with the exception of potassium ion with LOD $0.5 \mu \mathrm{g} \mathrm{sm}^{-3}$. A "Metrosep Dual 4-25" monolithic column (Metrohm-Peak, Houston, TX) was used for anion separation. Aerosol sample was continually collected over $60 \mathrm{~s}$ in a $90 \mu \mathrm{l}$ sample loop and injected into the column. Eluent of $12.0 \mathrm{mM}$ p-cyanophenol, $\mathrm{pH}$ adjusted (with $1.0 \mathrm{~N} \mathrm{LiOH}$ ) to $7.80 \pm 0.05$ isocratically separate chloride, nitrate, and sulfate. With PILS liquid flow rates used for this anion setup, limits of detection were chloride: $0.1 \mu \mathrm{g} \mathrm{sm}^{-3}$, nitrate: $0.02 \mu \mathrm{g} \mathrm{sm}^{-3}$, and sulfate: $0.02 \mu \mathrm{g} \mathrm{sm}^{-3}$.

The resulting time interval for one $\mathrm{PM}_{1.0}$ ion composition measurement was a 90 -s integrated sample every $2.45 \mathrm{~min}$ for cations, and a 60 -s integrated sample every $75 \mathrm{~s}$ for anions. All concentrations have been converted to a standard temperature and pressure $\left(273.15^{\circ} \mathrm{K}, 1013.25 \mathrm{hPa}\right)$.

A carbon monolith denuder and a set of etched glass honeycomb denuders coated with citric acid and sodium carbonate were located immediately upstream of the PILS-IC to eliminate gas interferences. Before each flight, a valve diverted sampled aerosol through a HEPA filter for quantifica-

\footnotetext{
${ }^{2}$ Dunlea, E., DeCarlo, P., Aiken, A., Kimmel, J., Bahreini, R., Peltier, R. E., Weber, R., Tomlison, J., Collins, D., Shinozuka, Y., McNaughton, C., Howell, S., Clarke, A., Emmons, L., Apel, E., Pfister, G., van Donkelaar, A., Millet, D., Heald, C., and Jimenez, J. L.: Evolution of Asian Aerosols During Transpacific Transport in INTEX-B, in preparation, 2008.
}

tion of backgrounds. Sulfate was the only ionic compound measured with detectable background interference, which was generally constant at $0.015 \mu \mathrm{g} \mathrm{l}^{-1}$ (equivalent to ambient aerosol concentration of $\sim 10 \mathrm{ng} \mathrm{sm}^{-3}$ ). The sulfate background was subtracted from the dataset.

The ion chromatographs were calibrated using known dilutions of NIST-traceable ion standards. Linear calibration curves forced through zero were established using five different standards of anions and cations that bracketed the expected range of concentrations typically observed for the flow rates employed and the estimated ambient aerosol concentration. Both cation and anion systems were calibrated using all five standards at the beginning and middle of the research mission. The anion column was also challenged with a single standard before most flights to verify peak retention time (which was very sensitive to eluent concentration and temperature), as well as peak area. At the end of the mission, the anion column calibration was re-verified; unfortunately, the cation column failed during the last local flight and could not be calibrated. Sensitivity changed by less than $\sim 5 \%$ throughout the duration of the mission for the anion and cation systems, based on the series of calibrations.

\subsection{PILS-TOC}

A second PILS coupled to a Sievers Total Organic Carbon analyzer quantified $\mathrm{PM}_{1.0}$ WSOC. The PILS was operated to produce a total sample liquid flow rate of $1.2 \mathrm{ml} \mathrm{min}^{-1}$. Following the removal of entrained gas bubbles in the liquid sample, the PILS effluent was aspirated by two glass syringe pumps working in alternating tandem to achieve continuous flow and pumped through a $0.5 \mu \mathrm{m}$ PEEK filter. Liquid sample was re-equilibrated with cabin pressure by using an inline sample line "tee" with one leg open to cabin air. Most of this sample $(1.0 \mathrm{ml} / \mathrm{min})$ was then drawn into the TOC analyzer via its internal peristaltic pump.

The TOC analyzer converts carbonaceous material to $\mathrm{CO}_{2}$ (carbon dioxide), and measures the evolved $\mathrm{CO}_{2}$ by conductivity. Oxidation of organic compounds was achieved by acidifying the sample, and then applying a combination of chemical (ammonium persulfate, $15 \% \mathrm{w} / \mathrm{w}$, flow rate $\left.=1.5 \mu 1 \mathrm{~min}^{-1}\right)$ and $\mathrm{UV}(\nu=184$ and $254 \mathrm{~nm}$ ) oxidation. Tests show that no EC and no insoluble OC larger than $\sim 0.1 \mu \mathrm{m}$ can be quantified with the TOC analyzer (Peltier et al., 2007b). The instrument was operated in "Turbo" mode to provide a 3-s integrated measurement every $3 \mathrm{~s}$. All concentrations have been converted to standard temperature and pressure $\left(273.15^{\circ} \mathrm{K}, 1013.25 \mathrm{hPa}\right)$.

Immediately upstream of the PILS-TOC, the sample was passed through an activated carbon parallel plate denuder (Eatough et al., 1999) to remove organic gases. During each flight, a computer-actuated valve was triggered every three hours to divert sample flow through a Teflon filter for a dynamic blank measurement. In general, before aircraft take off, and just after aircraft landing, the filter system was also 
manually triggered for blank measurements and to limit contamination associated with aircraft maneuvering while taxiing. A linear interpolation of consecutive blanks was calculated and subtracted from the online dataset to determine ambient WSOC concentrations. Though the instrument is factory calibrated, additional calibrations using 4 different concentrations of oxalic acid was conducted before and after the research mission. Near the middle of the mission, a single calibration standard was measured to verify analyzer sensitivity. In each case, analyzer sensitivity was within 5\% of factory calibration.

To provide an assessment of instrument accuracy, measurements of identical species made on the NSF C-130 and NASA DC-8 research aircraft were compared during periods of formation flying. A blind intercomparison from flight 12 (15 May 2006) showed that fine particle sulfate measured online with a mist chamber on the DC- 8 was essentially identical to fine particle sulfate measured by the PILS-IC on the $\mathrm{C} 130$ (slope: $1.00,1 \sigma=0.03 \mu \mathrm{g} \mathrm{sm}^{-3}$, range 0.25 to $\left.1.15 \mu \mathrm{g} \mathrm{sm}^{-3} ; n=40\right)$. The PILS-WSOC was only operated on the $\mathrm{C} 130$ and thus could not be compared with a similar instrument on the DC-8.

\subsection{Other instrumentation}

Additional instrumentation used in this work included a $\mathrm{CO}$ monitor using a modified UV resonance fluorescence instrument for $1 \mathrm{~Hz}$ measurements of carbon monoxide $(\mathrm{CO})$. The Trace Organic Gas Analyzer (TOGA) (Apel et al., 2003) was employed to measure a suite of 33 oxygenated volatile organic compounds that included: carbonyls, alcohols, and C2-C8 nonmethane hydrocarbons. TOGA is a fast gas chromatograph-mass spectroscopy (GC/MS) that provides a 45 -s integrated measurement every $\sim 2.5 \mathrm{~min}$. In addition, a variety of organic carbon compounds were detected by whole air sampling (WAS). These samples were subsequently analyzed by gas chromatography, mass spectrometry, flame ionization detection, or electron capture detection, depending on species measured. An onboard Proton Transfer Reaction-Mass Spectrometer (PTRMS) (Lindinger et al., 1998; de Gouw et al., 2003) quantified a variety of organic compounds, including hydroxyacetone and acetic acid. The sampling interval of this instrument was $\sim 33 \mathrm{~s}$. Water vapor mixing ratio was measured at $1 \mathrm{~Hz}$ by an onboard hygrometer. Physical measurements, such as altitude and latitude/longitude were provided by the $\mathrm{C} 130$ standard instrumentation package.

\subsection{Identifying air mass sources}

Various sources of measured anthropogenic species were identified with Flexpart, a Lagrangian particle dispersion model (Stohl et al., 1998, 2005). Flexpart backward runs were conducted whenever the aircraft changed latitude or longitude by 0.18 degrees, or when the aircraft altitude changed by $\sim 8-15 \mathrm{hPa}$. In general, Flexpart runs were completed every $\sim 30-60$ s for all research flights.

The Flexpart model provides estimates for the fraction of anthropogenic $\mathrm{CO}, \mathrm{SO}_{2}$, and $\mathrm{NO}_{2}$ from the following continents: Asia, Africa, North America, Australia, South America, and Europe. The calculations treated these substances as inert tracers, i.e., no deposition processes or chemical conversions were accounted for. The results, thus, reflect the accumulated emissions that entered the air mass during the 20 days the model was run backward from the observation locations. The emissions were taken from the EDGAR 3.2 Fast Track 2000 global inventory (Olivier and Berdowski, 2001), except for North America where the emissions were based on the point, on-road, non-road and area sources from the US EPA National Emissions Inventory, base year 1999 with updates for 2005, with spatial partitioning of area sources at $4 \mathrm{~km}$ resolution (Frost et al., 2006).

In this analysis, when Asian CO (as determined by Flexpart) exceeded $75 \%$ of total Flexpart-predicted $\mathrm{CO}$, the air mass was presumed to consist of mainly Asian emissions. When North American CO exceeded 75\% of total CO, the air mass was considered to be influenced mainly by North American sources. $\mathrm{CO}$ was chosen as a tracer because of the three anthropogenic species Flexpart predicts $\left(\mathrm{CO}, \mathrm{NO}_{2}\right.$, $\mathrm{SO}_{2}$ ), $\mathrm{CO}$ is likely the most inert on the time scales of interest here, and hence best tracer to identify long range transport. On average, $\mathrm{CO}$ from North America and Asia accounted for $>90 \%$ of total CO that was predicted by the model, indicating little influence from other continental sources. Of the 6078 Flexpart model runs analyzed, $\sim 48 \%(n=2931)$ were delineated as influenced by Asian pollution, $\sim 12 \%$ $(n=704)$ were mainly influenced by North American sources of $\mathrm{CO}$, and the remaining $\sim 40 \%$ were not dominated by either source. For air masses identified as mainly influenced by Asia or North America, measured $\mathrm{CO}$ mixing ratio during this mission was greater than $100 \mathrm{ppbv}$ in $93 \%$ and $97 \%$ of the observations, respectively. Thus, in cases that were identified using model results as influenced by Asia or North America, most cases had significant enhancements above background levels of $\mathrm{CO}$ and were only minimally affected by low concentration (e.g., background) observations. In the following, Asian, North American, and all data are analyzed.

\section{Results}

During the experiment, each research flight had defined objectives that depended on a variety of factors, including meteorological conditions, satellite overpass schedules, coordination with research flights of other aircraft involved in the INTEX campaign, and most importantly, model simulation predictions on the locations of Asian plumes. Figure 1 shows the sampling region. Because most INTEX-B research flights focused on measurements within aged plumes from Asia, the data are not statistically representative of local aerosol 
climatology; rather it represents measurements weighed by a focus on aged Asian air masses. On several occasions, specific plumes that were identified to be mainly influenced by more local sources in North America were encountered. These are analyzed as a subset of the North American data set.

\subsection{Aerosol composition by continental source}

Frequency distributions of measured concentrations were generally log-normally distributed and so geometric means and standard deviations are included in the analysis. Of measured components, $\mathrm{PM}_{1.0}$ mainly consisted of sulfate and then water-soluble organic carbon, as summarized in Table 1. For all data, median sulfate concentration $( \pm 1 \sigma)$ was $0.59 \pm 0.74 \mu \mathrm{g} \mathrm{sm}^{-3}$, and median WSOC was $0.3 \pm 0.8 \mu \mathrm{gC} \mathrm{sm}^{-3}$. Median ammonium concentration was at the detection limit, though mean concentration was $0.2 \pm 0.2 \mu \mathrm{g} \mathrm{sm}^{-3}$. Sodium ion was above the detection limit for just $10.2 \%$ of observations, and nitrate ion was above the detection limit $5.0 \%$ of the time. Calcium and chloride ion were above the detection limit just $0.1 \%$ and $0.2 \%$, respectively, and potassium and magnesium ions were not detected during the field campaign. The lack of sea-salt and mineral dust components is consistent with a $\mathrm{PM}_{1.0}$ measurement, since these compounds are mostly observed in supermicron particle sizes (Fitzgerald, 1991).

Contrasting air masses with mainly Asian CO sources to North American sources of $\mathrm{CO}$ shows that generally both sulfate and WSOC were higher in North American air masses. Median sulfate concentration was $0.84 \mu \mathrm{g} \mathrm{sm}^{-3}$ in North American plumes and $0.42 \mu \mathrm{g} \mathrm{sm}^{-3}$ in Asian plumes, with substantially more variability in Asian sulfate concentrations (range: LOD to $6.83 \mu \mathrm{g} \mathrm{sm}^{-3}$ in Asian plumes; LOD to $1.92 \mu \mathrm{g} \mathrm{sm}^{-3}$ in North American plumes). This is consistent with large Asian point sources of $\mathrm{SO}_{2}$. This was confirmed by assessing the data using a Wilcoxon rank-sum test (JMP, ver 5.0.1, SAS, Cary, NC), which showed statistically significant differences in sulfate concentration between each source region. It is noted, however, that our method of identifying North American emissions, based on CO, tends to focus on urban sources located near the west coast of the United States where there are relatively few $\mathrm{SO}_{2}$ sources.

In contrast to sulfate, median WSOC was a factor of 4 times higher in North American air masses (Table 1) than Asian air masses. Highest concentrations of WSOC could be traced with Flexpart to air masses from the Central Valley of California, as well as the immediate vicinity of Seattle. Not considering these plumes of highest WSOC concentration, North American plumes still had generally much higher WSOC than Asian plumes (median WSOC without Central Valley or Seattle plumes was $0.5 \mu \mathrm{gC} \mathrm{sm}^{-3}$ ). California Central Valley plumes are analyzed further in Sect. 3.4. The North American and Asian WSOC data were also assessed by Wilcoxon rank-sum test are were found to be significantly

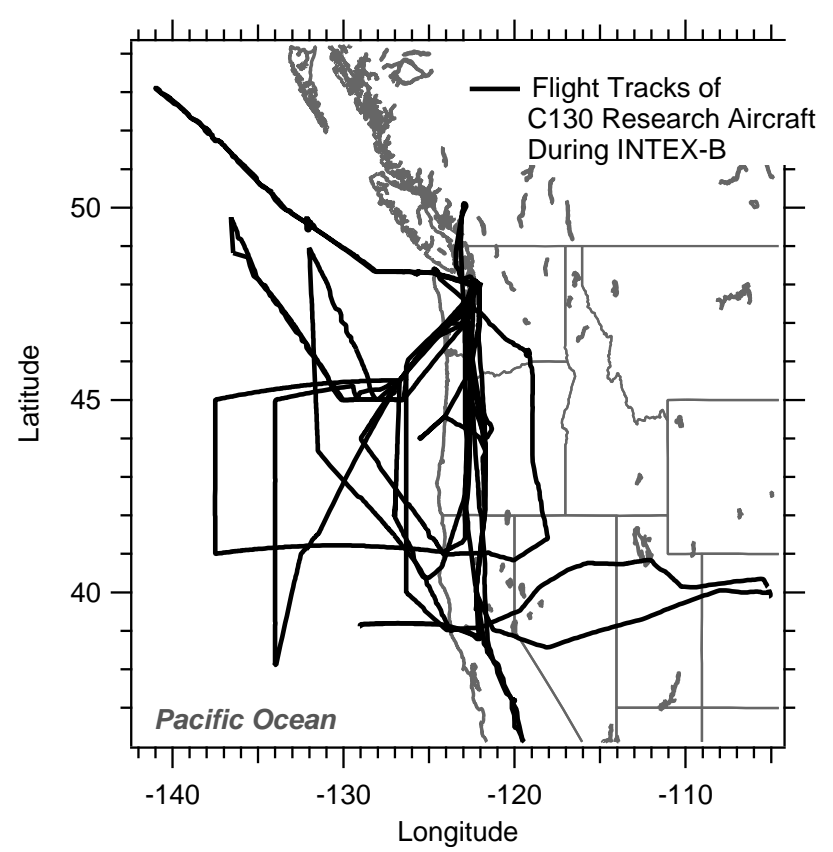

Fig. 1. NSF C130 research aircraft flight paths. The aircraft was based near Seattle, US $\left(47.91^{\circ} \mathrm{N},-122.28^{\circ}\right)$ from 21 April to 15 May 2006. Ten local research flights were conducted.

different. Plumes from Seattle are not investigated because interceptions were sporadic, recorded briefly during take-off and landing when many instruments were not operational.

Ammonium ion concentration was a factor of two higher in North American air masses compared to Asian air masses. Lastly, mean nitrate (median values are below the LOD) ion concentration in North American plumes $\left(0.07 \mu \mathrm{g} \mathrm{sm}^{-3}\right)$ was 7 times higher than observed in Asian air masses $\left(0.01 \mu \mathrm{g} \mathrm{sm}^{-3}\right.$, Table 1$)$, though nitrate was only infrequently observed above LOD for Asia interceptions (1\% of measurements were above LOD).

Most of the observations of sulfate and WSOC were representative of more regional conditions. This was especially true for the North American air masses. The ratio of mean to median concentration can provide some indication to the extent of large anomalous plumes in the data set. Interceptions of unique plumes with concentrations significantly above the regional values would lead to mean/median ratios significantly larger than 1 . Asian sulfate and WSOC had mean/median ratios of 1.6 and 2.5 , respectively, whereas North American air masses had ratios of 0.95 (sulfate) and 1.2 (WSOC). In both Asian and North American air WSOC and sulfate were not correlated $\left(r^{2}<0.03\right)$, suggesting different sources and atmospheric processing.

\subsection{Altitude profiles of WSOC and sulfate}

To provide a more detailed comparison on the distribution of aerosol composition, and for comparison with other studies, 
Table 1. Statistical summary of PILS observations during INTEX-B field campaign, including all data, observations mainly influenced by Asian emissions, and observations mainly influenced by North American emissions (according to Flexpart continental emissions product). Data includes all 10 local research flights as well as the two transit flights. For measurements below the detection limit, 1/2 the LOD was used in the statistical calculations. Time resolution for ion data is 60 second integral for anions, and 90 second integral for cations. WSOC data has been averaged to each Flexpart model run (approx every 30-60 s; refer to Flexpart summary for more information). All concentrations are $\mu \mathrm{g} \mathrm{sm}^{-3}$ for ion data, and $\mu \mathrm{gC} \mathrm{sm}^{-3}$ for WSOC at standard $T$ and $P\left(273^{\circ} \mathrm{K}\right.$ and $1 \mathrm{~atm}$, respectively).

\begin{tabular}{|c|c|c|c|c|c|c|c|c|c|c|}
\hline All Data & LOD & $n$ & $\%$ above LOD & Median & Mean & $1 \sigma$ & Meangeo $_{\text {geo }}$ & $1 \sigma_{\text {geo }}$ & Max & Min \\
\hline Sodium & 0.1 & 1652 & $10.2 \%$ & 0.05 & 0.09 & 0.17 & 0.06 & 0.66 & 1.8 & 0.05 \\
\hline Ammonium & 0.1 & 1846 & $37.1 \%$ & 0.10 & 0.21 & 0.24 & 0.08 & 0.7 & 3.2 & 0.05 \\
\hline Calcium & 0.1 & 1664 & $0.1 \%$ & 0.05 & 0.05 & 0.01 & 0.05 & 0.05 & 0.4 & 0.05 \\
\hline Potassium & 0.5 & 1664 & $0.0 \%$ & 0.25 & 0.25 & 0.0 & 0.25 & 0.0 & 0.25 & 0.25 \\
\hline Magnesium & 0.1 & 1846 & $0.0 \%$ & 0.05 & 0.05 & 0.0 & 0.05 & 0.0 & 0.05 & 0.05 \\
\hline Sulfate & 0.02 & 3452 & $96.7 \%$ & 0.59 & 0.77 & 0.74 & 0.50 & 1.10 & 7.03 & 0.01 \\
\hline Nitrate & 0.02 & 3464 & $5.0 \%$ & 0.01 & 0.03 & 0.14 & 0.01 & 0.70 & 1.01 & 0.01 \\
\hline Chloride & 0.1 & 3452 & $0.2 \%$ & 0.05 & 0.05 & 0.02 & 0.05 & 0.08 & 1.2 & 0.05 \\
\hline WSOC & 0.1 & 3644 & $67.1 \%$ & 0.3 & 0.6 & 0.8 & 0.25 & 1.47 & 5.7 & 0.1 \\
\hline Asia & LOD & $n$ & $\%$ above LOD & Median & Mean & $1 \sigma$ & Meangeo $_{\text {geo }}$ & $1 \sigma_{\text {geo }}$ & $\operatorname{Max}$ & Min \\
\hline Sodium & 0.1 & 669 & $6.7 \%$ & 0.05 & 0.08 & 0.12 & 0.06 & 0.56 & 1.10 & 0.05 \\
\hline Ammonium & 0.1 & 752 & $39.9 \%$ & 0.05 & 0.16 & 0.20 & 0.10 & 0.93 & 1.20 & 0.05 \\
\hline Calcium & 0.1 & 676 & $0.0 \%$ & 0.05 & 0.05 & 0.00 & 0.05 & 0.00 & 0.05 & 0.05 \\
\hline Potassium & 0.5 & 676 & $0.0 \%$ & 0.25 & 0.25 & 0.00 & 0.25 & 0.00 & 0.25 & 0.25 \\
\hline Magnesium & 0.1 & 752 & $0.0 \%$ & 0.05 & 0.05 & 0.00 & 0.05 & 0.00 & 0.05 & 0.05 \\
\hline Sulfate & 0.02 & 1235 & $96.2 \%$ & 0.42 & 0.68 & 0.82 & 0.41 & 1.14 & 6.83 & 0.01 \\
\hline Nitrate & 0.02 & 1235 & $1.5 \%$ & 0.01 & 0.01 & 0.02 & 0.01 & 0.29 & 0.65 & 0.01 \\
\hline Chloride & 0.1 & 1235 & $0.2 \%$ & 0.05 & 0.05 & 0.01 & 0.05 & 0.06 & 0.2 & 0.05 \\
\hline WSOC & 0.1 & 1742 & $56.5 \%$ & 0.2 & 0.5 & 0.6 & 0.19 & 1.37 & 4.3 & 0.1 \\
\hline North American & LOD & $n$ & $\%$ above LOD & Median & Mean & $1 \sigma$ & Mean $_{\text {geo }}$ & $1 \sigma_{\text {geo }}$ & $\operatorname{Max}$ & Min \\
\hline Sodium & 0.1 & 110 & $6.4 \%$ & 0.05 & 0.08 & 0.18 & 0.06 & 0.56 & 1.70 & 0.05 \\
\hline Ammonium & 0.1 & 119 & $60.5 \%$ & 0.10 & 0.26 & 0.40 & 0.14 & 1.05 & 3.20 & 0.05 \\
\hline Calcium & 0.1 & 110 & $0.0 \%$ & 0.05 & 0.05 & 0.00 & 0.05 & 0.00 & 0.05 & 0.05 \\
\hline Potassium & 0.5 & 110 & $0.0 \%$ & 0.25 & 0.25 & 0.00 & 0.25 & 0.00 & 0.25 & 0.25 \\
\hline Magnesium & 0.1 & 119 & $0.0 \%$ & 0.05 & 0.05 & 0.00 & 0.05 & 0.00 & 0.05 & 0.05 \\
\hline Sulfate & 0.02 & 210 & $98.1 \%$ & 0.84 & 0.80 & 0.34 & 0.68 & 0.78 & 1.92 & 0.01 \\
\hline Nitrate & 0.02 & 211 & $0.0 \%$ & 0.01 & 0.07 & 0.38 & 0.01 & 0.00 & 1.01 & 0.01 \\
\hline Chloride & 0.1 & 210 & $0.0 \%$ & 0.05 & 0.05 & 0.00 & 0.05 & 0.00 & 0.05 & 0.05 \\
\hline WSOC & 0.1 & 434 & $83.4 \%$ & 0.9 & 1.1 & 0.9 & 0.27 & 1.24 & 4.2 & 0.1 \\
\hline
\end{tabular}

the median WSOC and sulfate altitude profiles are plotted for the Asian and North American air masses. Data were binned into $250 \mathrm{~m}$ intervals below $2500 \mathrm{~m}$, and $500 \mathrm{~m}$ intervals above this altitude.

\subsubsection{Asian WSOC and sulfate}

As observed in other locations, Asian air mass WSOC concentrations were highest near the surface. The median WSOC below $3 \mathrm{~km}$ was $\sim 0.4-0.8 \mu \mathrm{gC} \mathrm{sm}^{-3}$, whereas above this altitude WSOC concentration rapidly decreased to below the limit of detection $\left(0.1 \mu \mathrm{gC} \mathrm{sm}^{-3}\right)$. Measurements of $\mathrm{OC}$ on the Asian coast during ACE-Asia were very different. Huebert et al. (2004a) measured relatively constant OC concentration with altitude, while Maria et al. (2003) measured slightly decreasing concentrations with altitude. In both cases, the OC concentration at higher altitudes ranged from $\sim 2-10 \mu \mathrm{gC} \mathrm{sm}^{-3}$, or approximately 10-20 times higher than WSOC observations at any altitude in our Asian air mass. A number of possibilities may explain the difference. The organic carbon measured in our study may not have been highly soluble and so not detected as WSOC (OC was measured in ACE-Asia). Emissions from Asia could have been substantially different for these two different study periods. The organic carbon aerosol may have been substantially diluted during transport, or the organic carbon was lost through, for example, precipitation scavenging.

It is unlikely that most of the OC remained insoluble since the air masses were well aged with transport times 

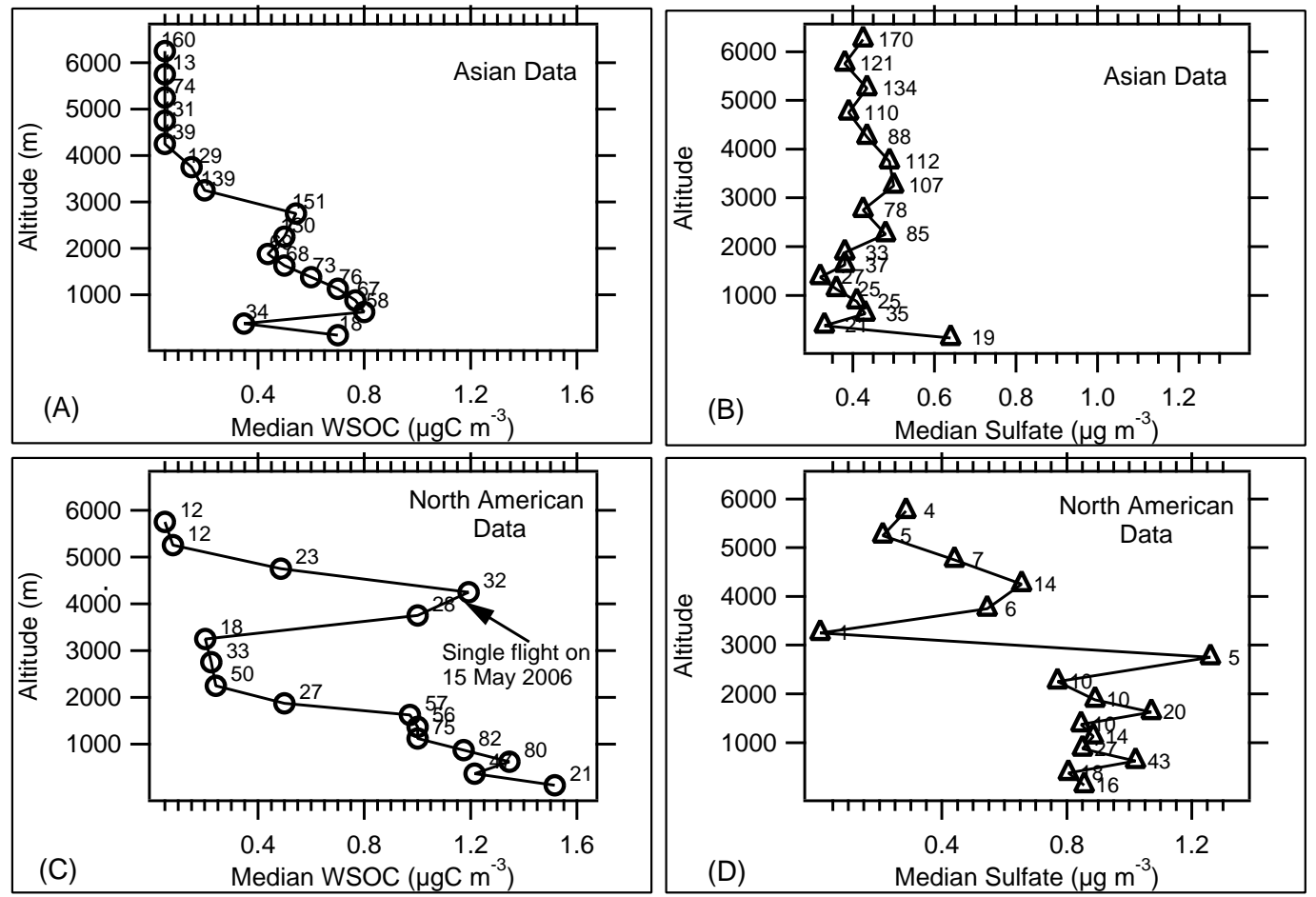

Fig. 2. Altitude profiles of median WSOC and sulfate concentration. Data is grouped into $250 \mathrm{~m}$ altitude bins below $2 \mathrm{~km}$, and $500 \mathrm{~m}$ bins above $2 \mathrm{~km}$. Number of observations for each bin are on the edge of the plot.

greater than $\sim 7$ days. Aged air has ratios of oxygenated organic matter to total organic matter, and hence WSOC/OC, typically near 1.0 (Zhang et al., 2007). Asian emissions have, if anything, increased in the last few years, so differences in emission cannot likely account for the factor of 10 to 20 lower WSOC measured along the Western United States coast. This is further supported by comparisons of $\mathrm{CO}$, an approximately inert tracer for anthropogenic or biomass burning sources on the time scales considered here. CO recorded from the NASA P-3B aircraft (similar operating altitude range as the NSF C130 of ACEAsia) during TRACE-P (held nominally concurrent with ACE-Asia) had mean CO of $178.3 \mathrm{ppb}(1 \sigma= \pm 89.3 \mathrm{ppbv})$, and median $\mathrm{CO}$ was $158.6 \mathrm{ppbv}$ (range: 67-808 ppbv), whereas in this study, INTEX-B Asian air masses had mean $\mathrm{CO}$ of $130.7 \mathrm{ppbv}(1 \sigma= \pm 23.9 \mathrm{ppbv})$, and median $\mathrm{CO}$ was $133.1 \mathrm{ppbv}$ (range: 72-316 ppbv). Assuming a springtime background concentration of $\mathrm{CO}$ as $100 \mathrm{ppbv}$, and that emissions from Asia have not substantially changed since TRACE-P, this very roughly suggests that pollutant concentrations decreased by a factor of 3 or less by dilution from transport across the Pacific (i.e, (mean TRACE-P CO minus background $\mathrm{CO}) /($ mean INTEX-B CO minus background $\mathrm{CO})$, or (178 ppb-100 ppb)/(131 ppbv-100 ppbv)). Based on these arguments it seems reasonable that loss in transport is a major cause for the relatively low WSOC concentrations observed in Asian air masses during INTEX-B. Satellite ev- idence that suggests possible precipitation loss is discussed further in Sect. 3.3.

In contrast to WSOC, sulfate aerosol concentrations in the Asian plumes recorded near North America were relatively constant across the sampled altitude range. Figure 2 shows that, at altitudes below $3 \mathrm{~km}$, median sulfate concentration was typically $0.35-0.50 \mu \mathrm{g} \mathrm{sm}^{-3}$. At higher altitudes, median sulfate was $0.40-0.45 \mu \mathrm{g} \mathrm{sm}^{-3}$. These concentrations are substantially different than what was observed by Lee and coworkers (2003) near the Asian continent, where 8$10 \mu \mathrm{g} \mathrm{sm}^{-3}$ of sulfate was recorded near the surface and a rapid decrease to $\sim 1-2 \mu \mathrm{g} \mathrm{sm}^{-3}$ above $4 \mathrm{~km}$. Although the vertical profile is somewhat similar, again concentrations appear to be significantly lower after advection, likely due to dilution and loss.

\subsubsection{North American WSOC and sulfate}

A somewhat similar altitude profile for WSOC was observed when the data was restricted to plumes mainly of North American influence. Overall, WSOC concentration decreased with increasing altitude. Below $2 \mathrm{~km}$, WSOC concentration was $\sim 1.0-1.5 \mu \mathrm{gC} \mathrm{sm}^{-3}$ and was mainly due to local Seattle emissions observed during take off and landing approaches, as well as some incidental air traffic control transiting near Seattle. A distinct increase in WSOC concentration was observed between $3-5 \mathrm{~km}$. These data were 


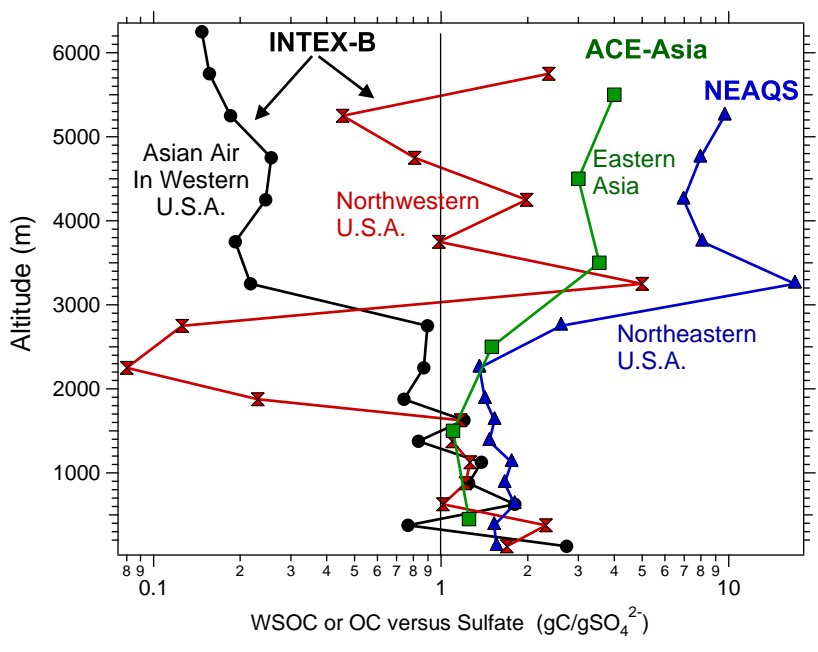

Fig. 3. Altitude profiles of the median ratio between WSOC or OC and sulfate aerosol measured during INTEX-B for data segregated into Asian and North American air masses. For comparison, also plotted are measurements off the Northeastern US measured during NEAQS 2004, and data collected off the coast of Asia during ACE-Asia, spring 2001, adapted from Heald et al. (2005). INTEX-B and NEAQS data are WSOC/Sulfate, and ACE-Asia data are OC/Sulfate.

recorded on a single flight that occurred on 15 May 2006 near Nevada, U.S.A. and was due to air masses from the California Central Valley (this plume is discussed more in Sect. 3.4). At altitudes above $\sim 5 \mathrm{~km}$, WSOC concentration decreased to approximately $0.1 \mu \mathrm{gC} \mathrm{sm}^{-3}$. This is higher than similar altitude WSOC concentrations in Asian air masses, which were below the LOD of $0.1 \mu \mathrm{gC} \mathrm{sm}^{-3}$, but similar to the WSOC concentrations of $\sim 0.3 \mu \mathrm{gC} \mathrm{sm}^{-3}$ at $\sim 5$ to $6 \mathrm{~km}$ altitude reported by Peltier et al. (2007a) near the Northeastern United States.

For sulfate aerosol, North American air masses were characterized by fairly uniform concentrations below $3 \mathrm{~km}$ altitude $\left(\sim 0.8-1.0 \mu \mathrm{g} \mathrm{sm}^{-3}\right.$ ), and significantly lower concentrations above $3 \mathrm{~km}\left(\sim 0.4 \mu \mathrm{g} \mathrm{sm}^{-3}\right)$. The free troposphere sulfate concentrations in North America air masses were similar to the free troposphere sulfate from Asian air masses, however, there are significantly fewer data available for an altitude profile of North American sulfate and thus not statistically significant.

\subsection{WSOC-Sulfate ratio with altitude}

As the two main components of fine particles in many regions, the ratio of OC or WSOC to sulfate can provide insight into differences in sources and processing. For example, in the Northeastern United States (NEAQS field campaign), the median ratio of WSOC to sulfate was observed to significantly increase with increasing altitude (Fig. 3) (Peltier et al., 2007a) suggesting that relative to sulfate, WSOC was either more efficiently lofted, removed less efficiently, and/or produced in situ at faster rates at altitudes between 3 and $5 \mathrm{~km}$. That study concentrated on urban regions of the northeast, as well as a region densely populated with coal-fired power generation facilities located $500-900 \mathrm{~km}$ to the west of New York City. A similar dominance of organic aerosol at higher altitudes was also recorded within $\sim 1000 \mathrm{~km}$ from the coast of the Korean peninsula, Japan, and the Asian continent during ACE-Asia (Heald et al., 2005). These results are also plotted in Fig. 3.

NEAQS and ACE-Asia sampled relatively fresh emissions. In contrast, the Asian air masses recorded in this study along the Northwestern US coast had undergone longrange transport $(6000-7000 \mathrm{~km})$ and the altitude profile of WSOC/sulfate is much different. As shown in Fig. 3, the INTEX-B Asian WSOC/sulfate profile tends to decrease with increasing altitude with a WSOC/sulfate ratio significantly below 1.0 in the free troposphere. On the other hand, INTEX-B North American observations were similar in trend to the results from NEAQS and ACE-Asia, with increasing WSOC/sulfate ratios above roughly $2 \mathrm{~km}$ a.s.l. (Fig. 3). However, free troposphere WSOC/sulfate ratios were not as high, possibly a result of Asian influence on the Northwestern United States aerosol climatology. Note that the much higher variability in the Northwestern US profile is likely due to a limited number of sulfate data points (see Fig. 2).

The differences in Asian air masses recorded in this study may be due to the effects of transport from Asia on WSOC and sulfate. A number of studies have shown that under clear skies the characteristic time-scale for secondary organic aerosol (SOA) formation in well defined urban plumes is on the order of $\sim 1$ day (Sullivan et al., 2006; de Gouw et al., 2007), while the oxidation time constant for sulfate formation from $\mathrm{SO}_{2}$ is approximately 3-4 days (Brock et al., 2007). Assuming the SOA and sulfate formation time constants described by these studies were similar for Asian outflow, this mechanism, coupled with precipitation scavenging of aerosols followed by reformation of aerosol during advection from Asia may be responsible for the WSOC/sulfate ratio observed in the free tropospheric Asian INTEX-B air masses.

In contrast to the free troposphere data (altitude roughly greater than $2 \mathrm{~km}$ ), the ratio of WSOC to sulfate mass in the boundary layer varied less, ranging from approximately 1 to 2 , regardless of the air mass origin. In these regions, WSOC and sulfate concentrations are generally much higher (Fig. 2), and this may be the cause of the observed lower variability in the WSOC/sulfate ratio.

Eastern Asia and the north central Pacific Ocean regions were subjected to significant precipitation and cloud cover during the INTEX-B study period, according to infrared satellite images of convective influence (http:// bocachica.arc.nasa.gov/INTEX_2006/index.html). Figure 4 is a schematic representation of a possible explanation for 


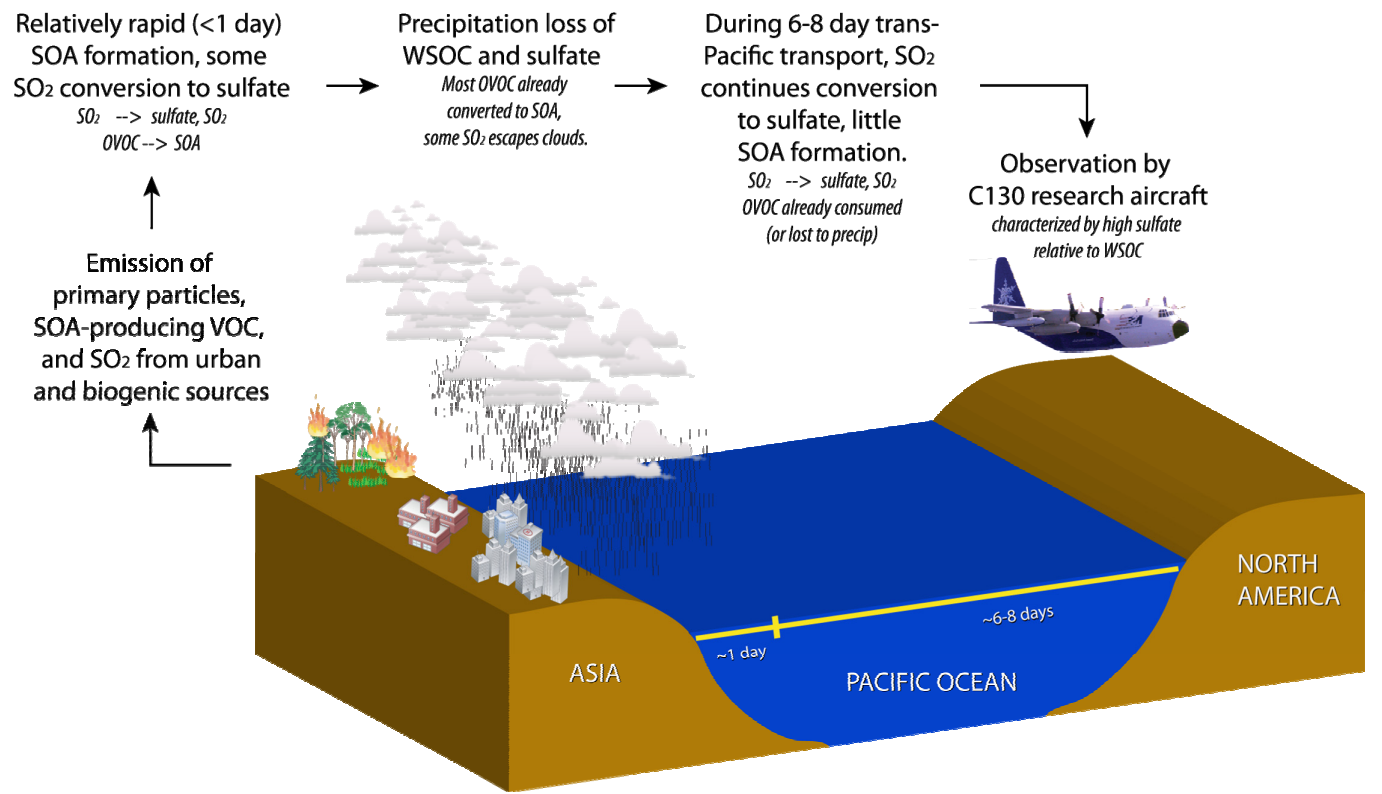

Fig. 4. Schematic of sulfate and SOA formation near the Asian continent with subsequent precipitation loss and sulfate replenishment during transport. The schematic attempts to explain the differences in observed WSOC/Sulfate ratios recorded near Asia in other studies, and Asian air masses recorded near North America during this study.

observed differences between WSOC and sulfate at various locations that involves a combination of aerosol formation, loss, and replenishment. If most anthropogenic SOA (hence WSOC) is formed rapidly downwind of urban regions (de Gouw et al., 2005; Sullivan et al., 2006; de Gouw et al., 2007), much of the WSOC could be lost by precipitation scavenging during advection to North America. Any primary WSOC from biomass burning and sulfate formed prior to precipitation would also be lost. However, aerosols can reform if the precursor gases penetrate the region of precipitation. Measurements show that because $\mathrm{SO}_{2}$ is not highly water-soluble, sulfate can be reformed down-wind of precipitating clouds (Weber et al., 2001; Brock et al., 2004). Our observation that WSOC concentration was much lower relative to sulfate in the Asian air masses measured near the Northwestern United States suggests that there was little reformation of WSOC in comparison to sulfate. One would expect that some VOCs may also penetrate the clouds, but if this line of reasoning is correct, they apparently do not lead to significant concentrations of SOA. The overall result is that Asian sulfur emissions may be more readily transported long distances than organic aerosols and their precursor VOCs, and hence sulfate will tend to dominate Asian anthropogenic impacts in North America.

\subsection{Investigating sources of WSOC}

As the two main components of $\mathrm{PM}_{1.0}$ in this study, the sources of sulfate and WSOC are of interest. Sulfate sources are well established and generally well predicted in model simulations (Heald et al., 2005; Nowak et al., 2006), whereas this is not the case for carbonaceous aerosols, especially organic carbon. For this reason, possible sources for WSOC measured in this study are investigated further.

\subsubsection{CO, water vapor, and WSOC}

Our previous work focusing on SOA formation in urban plumes showed a strong correlation between WSOC and CO (Sullivan et al., 2006; de Gouw et al., 2007; Weber et al., 2007) indicating that WSOC and CO sources were strongly linked in some manner. Those studies involved airborne measurements in relatively fresh, well defined, urban plumes (aged $<4$ days). In contrast, the INTEX-B measurements were of well-aged Asian air masses that had undergone transPacific transport ( $>7$ days) and North American air masses mainly representative of regional conditions. WSOC and $\mathrm{CO}$ were not correlated (Fig. 5, $r^{2}=0.06$ Asian, 0.08 North American) and WSOC could not be linked to specific sources using this method. However, there were two notable interceptions of plumes in the North America data set where enhancements in WSOC concentrations could be linked to a specific source region. On 3 May 2006, measurements were made in the vicinity of the California Central Valley and air trajectory analysis suggested Central Valley plumes of 1-2 days old. Other sources, such as urban regions along the California coast are also possible, however, we refer to these air masses as Central Valley plumes. These plumes 

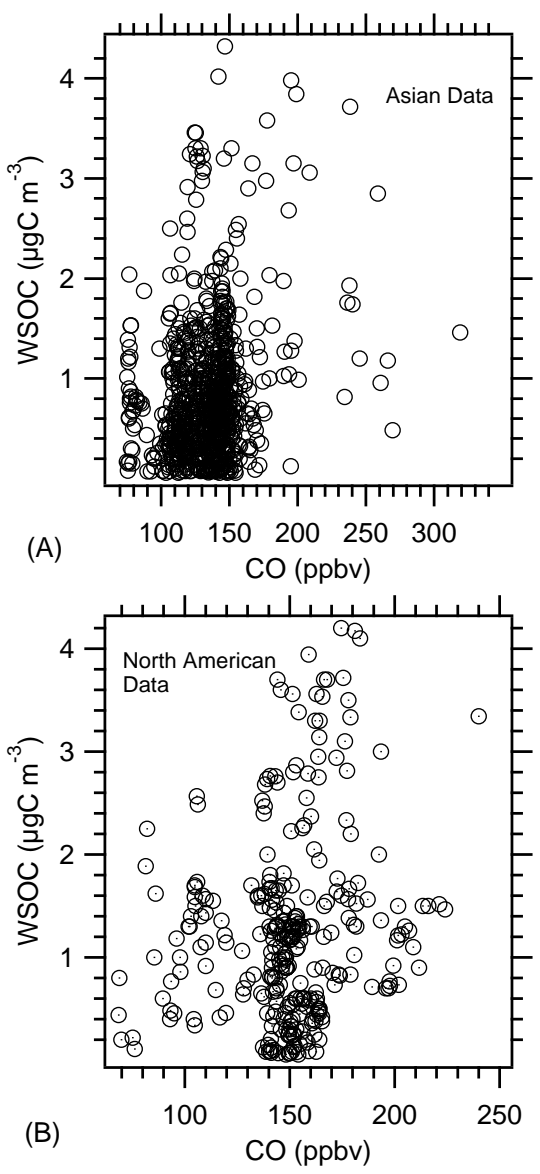

Fig. 5. Univariate regression analysis of WSOC and CO for data segregated into Asian (A) and North American (B) air mass data.

were intercepted at 21:50:30-22:05:00 UTC and again at 22:16:00-22:33:30 UTC at an altitude of $600 \mathrm{~m}$ a.s.l. On 15 May 2006, between 20:51 and 22:10 UTC, a region of enhanced WSOC concentration was intercepted over Northern Nevada at an altitude of 3 to $5 \mathrm{~km}$ a.s.l. This plume can be seen in North American median WSOC profile of Fig. 2. Flexpart indicated plumes from the Central Valley that were 2-3 days old. Maps showing the locations of both plumes are given in Fig. 6. The low altitude fresher plume was detected in a region of clear sky with broken cloud cover at altitudes of $6.4 \mathrm{~km}$ a.s.l., based on archived METARs from the Central Valley during the flight (available online at: http://vortex.plymouth.edu/sa_parse-u.html). The air mass sampled may have been recently cloud processed, however, we have found no evidence that permits a strong conclusion either way. The second plume from the Central Valley was recorded directly down-wind of a heavily clouded region, based on both aircraft video and satellite data (cloud optical thickness based on MODIS Aqua).

For each of these flights, WSOC and CO were moderately correlated (Fig. 6). The coefficient of determination between WSOC and CO during the flight near the Central Valley was
0.52. The Central Valley plume that was intercepted after transport to the Northern Nevada region had a slightly higher correlation of $r^{2}=0.59$. Univariate linear regression slopes of $50 \pm 1$ and $52 \pm 9 \mu \mathrm{gC} \mathrm{sm}^{-3} / \mathrm{ppmv}$, respectively, were somewhat higher than the range of slopes reported for New York City (Sullivan et al., 2006) and Atlanta, United States, (Weber et al., 2007) urban plumes (30 to $40 \mu \mathrm{gC} \mathrm{sm}^{-3} / \mathrm{ppmv}$ ).

Correlation between WSOC and water vapor in these plumes was also noteworthy (Fig. 6). Studies have shown that SOA formation may readily occur in aqueous solutions and may be enhanced by higher relative humidity (Lim et al., 2005; Matsunaga et al., 2005; Altieri et al., 2006; Carlton et al., 2006). Both water vapor concentration and relative humidity are moderately correlated with WSOC during the observation above the Central Valley (water vapor $r^{2}=0.45$, Fig. 6; RH $r^{2}=0.40$, not shown), and better correlated in the observation over Northern Nevada downwind of clouds (water vapor $r^{2}=0.74$, RH $r^{2}=0.80$ ). These plumes are further discussed in Sect. 3.4.3. In an attempt to discern contributions of anthropogenic and biogenic sources to the WSOC observed in the Asian and North American air masses, and the Central Valley plumes, a multivariate regression analysis is performed.

\subsubsection{Multivariate regression to investigate WSOC sources}

Measured VOCs, when compared with WSOC, may provide insights into specific WSOC sources. The previous analyses have focused on comparisons of WSOC with single variables (e.g. CO, water vapor, altitude, etc.). In order to further identify WSOC sources, a multivariate linear regression model of WSOC and VOC data was constructed. Principle component analysis (PCA) is often used to identify general sources that have impacted ambient field studies that would not be apparent from a single correlation analysis (Hopke et al., 1998; Wang et al., 2000; Hopke et al., 2003; Millet et al., 2004, 2005, 2006; Quinn et al., 2006; Kim and Hopke, 2007; Shim et al., 2007). PCA is used to reduce a large number of variables into smaller and more meaningful sets of variables that account for most of the observed variability in the dataset. Known sources for compounds can then be used in identifying the source for each principle component. This is particularly useful when a large number of variables are correlated. A disadvantage to this technique is that inferences from specific variables are limited because they have been grouped together with like variables. Multivariate linear regression directly relates a dependent variable to a specific set of independent variables. In these techniques, multivariate linear regression coefficient variables can be compared to one another to provide some indication of the relative importance of each variable. However, a significant disadvantage to this technique is that the results are largely dependant on the variables that are chosen for the regression analysis. The multivariate regression model is described in Eq. (1), where 

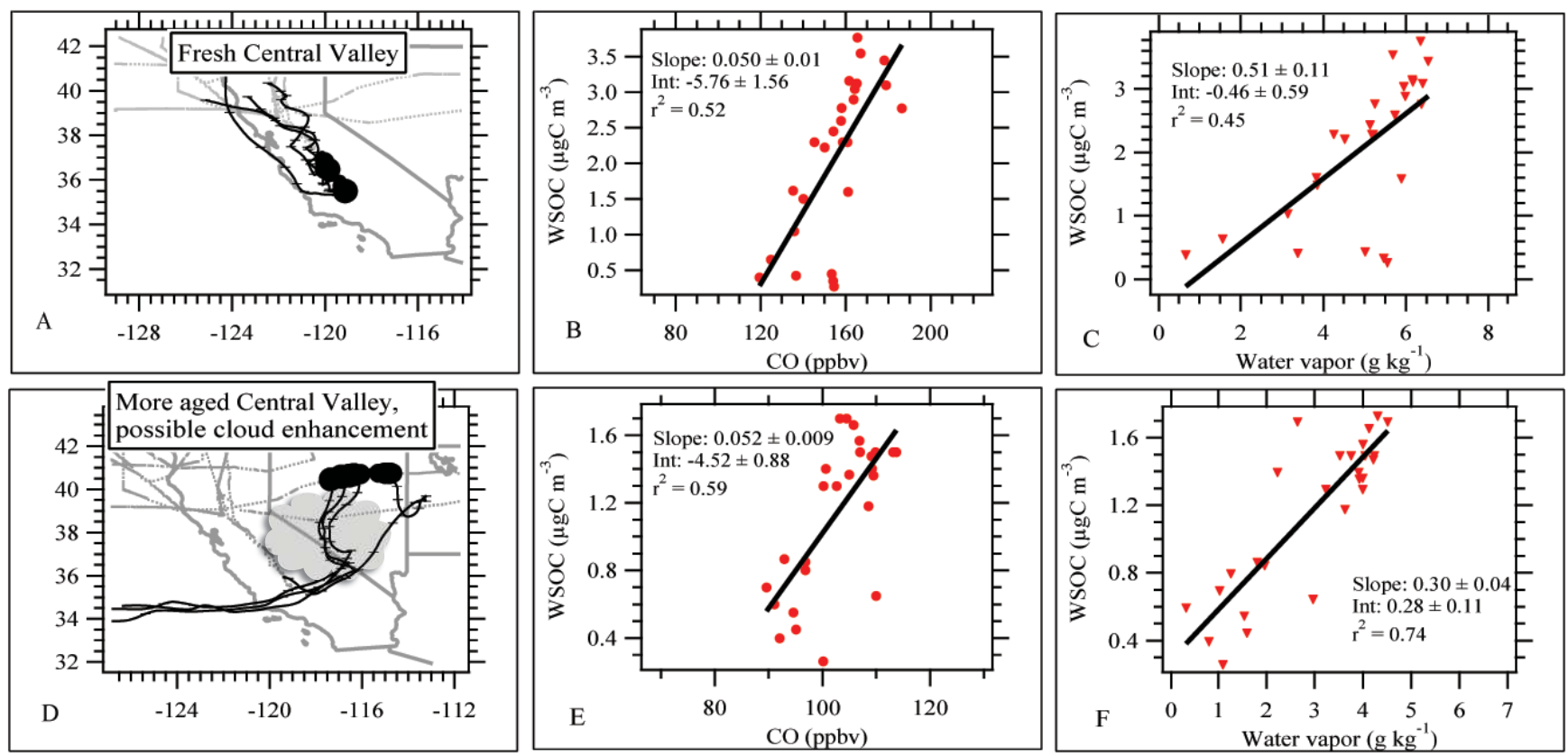

Fig. 6. (A) Location of relatively fresh, low altitude Central Valley plumes with $96 \mathrm{~h}$ HYSPLIT back trajectories. Shaded box represents Central Valley; (B) Univariate regression analysis of WSOC and CO; (C) WSOC and water vapor for Central Valley California plumes; (D) Location of Central Valley plume (black circles) over Nevada with 96 h HYSPLIT back trajectories. Shaded box represents Central Valley, and cartoon represents region of clouds observed directly downwind of the measurements; (E) Univariate regression analysis of WSOC and $\mathrm{CO}$; (F) WSOC and water vapor for cloud-influenced Central Valley California plumes.

$\beta_{0}$ is the intercept, and $\beta_{1}$ to $\beta_{i}$ are the regression coefficients for independent variables $x_{1}$ to $x_{i}$.

$y=\beta_{o}+\beta_{1} x_{1}+\beta_{2} x_{2}+\ldots \beta_{i} x_{i}$

There were a number of VOC measurements made aboard the $\mathrm{C} 130$ research aircraft that can be used as tracers of fossil fuel combustion or biogenic (including biomass burning) emissions. Fossil fuel combustion VOCs chosen for this analysis were mainly alkanes and aromatics. Biogenic VOCs were mainly alcohols and organic acids, and also included acetonitrile, a gas tracer for biomass burning. The VOCs selected for fitting with WSOC are summarized in Table 2. While none of the selected VOCs are perfectly unique tracers for fossil fuel combustion, biomass burning, or biogenic-non-biomass burning sources, compounds that have been shown to be emitted by mainly fossil fuel combustion or mainly biogenic sources were selected (Guenther et al., 1995; Heikes et al., 2002; Jacob et al., 2002; Spaulding et al., 2003; Singh et al., 2004; Jacob et al., 2005; Lewis et al., 2005). For example, acetonitrile does have some small industrial sources, and may be formed as a secondary compound, but the largest source of acetonitrile in the atmosphere is from biomass burning (Reiner et al., 2001; de Gouw et al., 2003).

Because the frequency distribution of the bulk concentration data were lognormally distributed, prior to regression analysis, the natural log for each data point for all variables was calculated to transform the frequency distributions to more normal distributions. Subtracting the geometric mean concentration or mixing ratio from each measurement, and then dividing by the variable geometric standard deviation, standardized the dataset for each variable. This shifts the mean of the sample to 0 and standardizes the data variability (e.g. $1 \sigma= \pm 1,2 \sigma= \pm 2$, etc.). The transformation eliminates potential bias introduced into the model caused by the wide range of concentrations observed in the dataset, giving equal weight to all variables independent of magnitude. Model multivariate linear regression coefficients can then be compared to one another without consideration to original concentration of the variables (Kim and Ferree, 1981). Our interest here is the source of VOCs with highest coefficients (e.g., fossil fuel, biogenic, biogenic from biomass burning).

Backward stepwise multivariate linear regression analysis was performed on the data to model WSOC concentration, where a variable was included when the t-statistic exceeded 2 (i.e., significant at the 5\% level). The variables were also checked for multicollinearity and if found, one variable was removed from the model to eliminate redundancy. The independent variables listed in Table 2 were used to analyze the dataset, and include many VOCs that have atmospheric lifetimes greater than the expected transport time from Asia ( $\sim 5-8$ days). Fossil fuel and biogenic VOC variables were 
Table 2. Summary of independent variables and their Henry's Law Constant values used to fit multivariate regression model. The VOCs are separated into either mainly from fossil fuel combustion, or biogenic sources, which includes biomass burning (acetonitrile) and secondary VOCs linked to biogenic emissions.

\begin{tabular}{llll}
\hline Fossil Fuel VOCs & $\mathrm{k}^{\circ} \mathrm{H}$ at $298.15 \mathrm{~K}\left(\mathrm{~mol} / \mathrm{kg}^{*} \mathrm{bar}\right)$ & Biogenic VOCs & $\mathrm{k}^{\circ} \mathrm{H}$ at $298.15 \mathrm{~K}\left(\mathrm{~mol} / \mathrm{kg}^{*} \mathrm{bar}\right)$ \\
\hline 1,1,1-trichloroethane & $0.058^{\mathrm{b}}$ & Methyl chloride & $0.12^{\mathrm{b}}$ \\
Methylethylketone & $20^{\mathrm{a}}$ & Methanol & $140^{\mathrm{b}}$ \\
Isopentane & $0.00072^{\mathrm{b}}$ & Hydroxyacetone & $\mathrm{n} / \mathrm{a}$ \\
Pentane & $0.00078^{\mathrm{b}}$ & Acetonitrile & $49^{\mathrm{b}}$ \\
Butane & $0.0011^{\mathrm{b}}$ & Isoprene & $0.028^{\mathrm{b}}$ \\
Acetaldehyde & $9.8^{\mathrm{b}}$ & Acetone & $30^{\mathrm{a}}$ \\
Isobutane & $0.00086^{\mathrm{b}}$ & Acetic Acid & $5400^{\mathrm{a}}$ \\
Toluene & $0.16^{\mathrm{b}}$ & & \\
Benzene & $0.16^{\mathrm{b}}$ & & \\
Methyl tertiary butyl ether & $\mathrm{n} / \mathrm{a}$ & & \\
Isopropyl nitrate & $\mathrm{n} / \mathrm{a}$ & & \\
o-xylene & $0.19^{\mathrm{a}}$ & & \\
n-pentane & $0.00078^{\mathrm{b}}$ & & \\
\hline
\end{tabular}

a adapted from Staudinger and Roberts (1996)

$\mathrm{b}$ adapted from Yaws (1992)

combined in the regression model to predict WSOC variability. It should be noted that this analysis does not predict whether specific VOCs form WSOC, rather it uses VOCs as tracers to describe conditions when WSOC can be observed.

As a result of using a linear multivariate regression analysis, it is not likely that the model will fully capture WSOC variability. The $\mathrm{C} 130$ research aircraft was equipped to measure just $\sim 60$ different VOCs by several different analytical techniques. Since WSOC formation involves highly complex and, as of yet, largely unknown VOC chemistry, there are undoubtedly a number of VOCs that play an important role in WSOC formation but were not included in the regression.

Table 3 summarizes the multivariate regression analysis for INTEX-B data that is mainly influenced by Asian emissions. The combined VOC sources of WSOC account for $49.3 \%$ of the observed variability. Thus, a significant fraction of WSOC variability is unaccounted for in this analysis. Several factors that were not quantified could explain the missing variability in the regression model. For example, cloud and precipitation losses of WSOC aerosol, which does not result in appreciable losses of VOCs, is one such mechanism that might explain the discrepancy. Similarly, VOCs may have been transformed in ways that do not lead to WSOC formation, resulting in a change in VOC concentration but no change in WSOC. Also, since observed WSOC concentration in Asian air masses was frequently below the limit of detection, it is not surprising that this model does not capture all of the variability for well-aged (and traveled) air masses. Regression analysis of North American air masses yielded different results (Table 3). Overall, these covariates explain $75.7 \%$ of the WSOC variability.
Comparing the standardized multivariate linear regression coefficients (Table 3) may provide some insight into generalized sources of WSOC. The absolute values of coefficients have been ranked from largest to smallest (Table 3). The absolute value is used since any process that leads to WSOC variability is of interest. For example, a negative coefficient could imply that the processes that produce WSOC are also, in some way, linked to loss of that VOC. A positive coefficient could result if the VOC and WSOC have similar sources. This points out a limitation with this method that introduces uncertainty with this analysis; some covariability of a VOC with WSOC may not be linked to WSOC formation in any physical manner. For example, WSOC formed in high oxidizing environments can lead to more WSOC, but some VOCs not linked to WSOC in any way may also be lost, independent of the VOC source (biogenic or anthropogenic).

Fossil fuel combustion VOC tracers are most closely associated with WSOC concentration in Asian plumes (Table 3). Isobutane, methyl ethyl ketone (MEK), and isopropyl nitrate coefficients are significantly larger than the remaining regression variables (it is noted, however, that all variables in this analysis are significant since each has been evaluated by student t-test). The remaining coefficients, including acetonitrile, a biomass burning tracer, contribute to variability in WSOC, but fossil fuel combustion VOCs explain most of the variability that could be accounted for in this model.

In contrast, North American WSOC that was observed in the Western U.S. is more closely associated with both biogenic and fossil fuel combustion VOCs. Pentane and hydroxyacetone are the largest contributors to WSOC variability. Pentane is a VOC associated with fossil fuel combustion, 
Table 3. Multivariate linear regression coefficients for selected VOC independent variables described in Table 2. Data has been split (using Flexpart) into air masses mainly influenced by North America, and air masses mainly influenced by Asia.

\begin{tabular}{lrrrr}
\hline Asian data & & N American data & \\
\hline Significant VOC & $\begin{array}{r}\text { Model Coefficient, } \beta_{i} \\
\text { (Standard error) }\end{array}$ & $\begin{array}{c}\text { Adjusted Model } \\
R^{2}\end{array}$ & $\begin{array}{l}\text { Significant VOC } \\
\text { Model Coefficient, } \beta_{i}\end{array}$ & $\begin{array}{c}\text { Adjusted Model } \\
\text { (Standard error) }\end{array}$ \\
\hline Isobutane & $1.16(0.27)$ & & Pentane & $1.43(0.60)$ \\
MEK & $-0.94(0.33)$ & Hydroxyacetone & $-1.27(0.25)$ \\
Isopropyl nitrate & $0.90(0.23)$ & & Isobutane & $-1.18(0.44)$ \\
Isopentane & $-0.51(0.34)$ & \multirow{2}{*}{$49.3 \%$} & Acetaldehyde & $1.18(0.51)$ \\
Acetaldehyde & $0.37(0.18)$ & & Acetone & $-0.87(0.55)$ \\
1,1,1-trichloroethane & $0.33(0.14)$ & & Acetic acid & $0.59(0.22)$ \\
Acetonitrile & $0.27(0.16)$ & & Methyl chloride & $0.56(0.19)$ \\
Constant, $\beta_{0}$ & $0.00(0.15)$ & & Constant, $\beta_{0}$ & $0.30(0.31)$ \\
\hline
\end{tabular}

and hydroxyacetone is a photo oxidation product of isoprene (Yu et al., 1995). Other significant fossil fuel combustion VOCs that contribute to WSOC variability include isobutane and acetaldehyde. Significant biogenic VOCs include acetone, acetic acid, and methyl chloride. These results suggest that both biogenic (but not biomass burning) and anthropogenic sources contributed to WSOC variability in North American air masses that impact the Western United States. In the North American data set, WSOC variability was not significantly affected by acetonitrile, indicating a limited influence on WSOC by biomass burning.

The contrast between the regression results for Asian versus North American air masses is also consistent with expectations. Higher anthropogenic sources of WSOC relative to biogenic sources in Asian air masses versus Northwestern United States air masses are expected given the proportions of anthropogenic and biogenic sources in the two regions. Asian emissions from more northern regions (e.g., China) advected westward are heavily influenced by large population centers, whereas the Northwestern United States is not highly populated but is heavily forested.

\subsubsection{Regression analysis on WSOC Central Valley plumes}

The regression was performed in the same manner for the two California Central Valley plumes encountered during INTEX-B. The first Central Valley plume (low altitude measurements made near the valley) was characterized by elevated VOCs and WSOC $\left(2-4 \mu \mathrm{gC} \mathrm{sm}^{-3}\right)$. Due to data availability limitations, hydroxyacetone and acetic acid (both biogenic VOCs) are not included in the analysis. There are, however, a number of other VOCs included in the regression analysis (Table 2) that can be used to identify biogenic sources. Thus, we may not be able to directly compare these results with the Asian and North American air mass regressions. Methylethylketone (MEK), methanol, and pentane are statistically significant VOCs that were identified in the regression model predicting WSOC variability (Table 4). Methylethylketone and pentane are associated with fossil fuel combustion. In contrast, methanol sources are predominately biogenic, though there is evidence of small sources related to fossil fuel combustion (Jacob et al., 2005) (methanol from fossil fuel combustion accounts for $\sim 1-2 \%$ of global methanol loading). Comparing multivariate linear regression coefficients (again, using the absolute value), biogenic sources are similar $(0.97 \pm 0.13$, Table 4$)$ to fossil fuel combustion sources $\left(\Sigma_{\beta}=1.74 \pm 0.46\right.$ by RMS) for WSOC variability, suggesting that in the Central Valley, WSOC is related to both fossil fuel combustion and biogenic sources of VOCs. This model accounts for $\sim 98.2 \%$ of the variability of WSOC (Table 4).

The second Central Valley plume intercepted over Northern Nevada in a region directly downwind of extensive clouds was characterized by elevated WSOC concentrations (1$2 \mu \mathrm{gC} \mathrm{sm}^{-3}$ ), elevated oxygenated VOCs (e.g. methanol, acetic acid, acetone), and $\mathrm{CO}$, and relatively low anthropogenic VOCs (e.g. benzene). For this plume, a number of statistically significant VOCs were observed in the multiple regression model of WSOC variability. Methanol and hydroxyacetone - both biogenic VOC tracers - comprise the largest multivariate linear regression coefficients of all parameters tested (Table 2). MEK and 1,1,1-tricholorethane, which are associated with fossil fuel combustion, and acetone (a biogenic tracer) have similar $\beta$-coefficients (Table 5), and are somewhat less important. Lastly, pentane and benzene, two VOCs associated with fossil fuel combustion, are also significant determinants of WSOC variability, though their $\beta$-coefficients are considerably smaller than the other VOCs (Table 5). The model accounts for $92.6 \%$ of the variability of WSOC during observations downwind of clouds. By summing the significant VOCs by their $\beta$-coefficient, biogenic sources appear to be most related to WSOC variability ( $\sim 66 \%$ ), though fossil fuel combustion VOC tracers also appear to be involved ( $\sim 33 \%)$. 
Table 4. Multivariate linear coefficients and statistics for selected VOC independent variables described in Table 2. Data is from a single plume during a flight on 3 May 2006 in the Central Valley of California.

\begin{tabular}{lrccc}
\hline Parameter & $\beta$-coefficient & Standard error & t-statistic & P-Value \\
\hline MEK & -1.22136 & 0.429068 & -2.84655 & 0.0159 \\
Methanol & 0.97262 & 0.130999 & 7.42463 & 0 \\
Pentane & 0.52521 & 0.174838 & 3.00398 & 0.012 \\
\hline
\end{tabular}

Adjusted model $R^{2}=98.2 \%$.

Table 5. Multivariate linear regression coefficients and statistics for selected VOC independent variables described in Table 2. Data is from a single plume during a flight on 15 May 2006 in Northern Nevada.

\begin{tabular}{lrcrc}
\hline Parameter & $\beta$-coefficient & Standard error & t-statistic & P-Value \\
\hline Methanol & -9.60911 & 2.54281 & -3.77893 & 0.0129 \\
Hydroxyacetone & 6.06393 & 1.4457 & 4.19446 & 0.0085 \\
MEK & 4.87372 & 1.29285 & 3.76975 & 0.013 \\
1,1,1-tricholoroethane & 4.82808 & 1.37575 & 3.50941 & 0.0171 \\
Acetone & 4.33436 & 1.42781 & 3.03566 & 0.0289 \\
Pentane & -2.78377 & 0.647055 & -4.30222 & 0.0077 \\
Benzene & -2.14162 & 0.788449 & -2.71624 & 0.042 \\
\hline
\end{tabular}

Adjusted model $R^{2}=92.6 \%$.

Despite having similar source regions (i.e., roughly same region of the Central Valley or urban regions on California coast, as indicated by Flexpart), WSOC for each plume appears to have a different association with VOCs. Based on visual and satellite evidence of clouds in the vicinity during the Nevada flight segment, higher correlations with water vapor (Fig. 6), and differences in altitudes at which the two Central Valley plumes were detected, the Nevada plume is more likely to have been recently influenced by cloud processing. Recent work by Sorooshian et al. $(2006,2007)$ has shown that clouds efficiently produce SOA, with highest concentrations of SOA frequently observed above clouds. Thus, SOA formation by clouds may account for some of the differences in multiple regression results.

In the cloud-outflow region, the overall analysis result is suggestive of WSOC (i.e., SOA) formation by heterogeneous processes involving liquid water and biogenic VOCs, as has been proposed in a number of other studies (Pun et al., 1999, 2002; Tsigaridis and Kanakidou, 2003; Baltensperger et al., 2005; Hartz et al., 2005; Hastings et al., 2005; Lim et al., 2005; Na et al., 2006; Varutbangkul et al., 2006). This type of mechanism may, at least in part, explain the generally higher WSOC/sulfate ratios (e.g., Fig. 3) observed in free tropospheric continental air masses in this and other studies (Peltier et al., 2007a), and may explain poor model prediction of free tropospheric organic aerosol mass and spatial distributions (Heald et al., 2005, 2006).

\section{Conclusions}

Airborne measurements in spring 2006 of fine particle $\left(\mathrm{PM}_{1.0}\right)$ bulk chemical composition were made from the surface to $\sim 7 \mathrm{~km}$ attitude over Western United States and Canada, and the Eastern Pacific Ocean. The online measurements included ionic species chloride, nitrate, sulfate, sodium, ammonium, potassium, calcium and magnesium, and the water-soluble organic carbon (WSOC) fraction of the organic aerosol. Data were analyzed separately according to continental source by using the Flexpart dispersion model to identify continents of influence based on CO sources. A particular emphasis on WSOC sources is discussed.

Submicron aerosol mass was dominated by water soluble organic carbon and sulfate, with additional contribution to mass by ammonium, nitrate and sodium ions. WSOC concentration was highest in North American air masses (median $=0.9 \mu \mathrm{gC} \mathrm{sm}^{-3}$ ), and lower in Asian outflow (median $=0.2 \mu \mathrm{gC} \mathrm{sm}{ }^{-3}$ ). Overall, sulfate aerosol had similar concentrations for Asian and North American observations.

WSOC concentration was highest at lowest altitude ranges in both North American and Asian air masses, though several enhancements in particular altitude ranges were observed. WSOC was also compared to sulfate concentration, and analyzed across altitude. Contrary to previous findings near Asia and near the Northeastern United States, the ratio of WSOC-to-sulfate in aged Asian air masses tended to decrease with altitude. Consistent with the mechanism proposed by Brock et al. (2004), we propose this was likely 
caused by precipitation loss of aerosol prior to observation, followed by preferential replenishment of sulfate aerosol as the air mass was transported across the Pacific. Since observations were generally not of fresh, urban emissions, WSOC and $\mathrm{CO}$ were poorly correlated. However, in two distinct WSOC plumes observed during this experiment, WSOC and $\mathrm{CO}$ were well correlated $\left(r^{2}=0.5\right.$ to 0.6$)$. A similar finding was observed when comparing WSOC with water vapor mixing ratio.

Both Asian and North American plumes were investigated by multivariate regression analysis using a number of tracer VOCs that were representative of fossil fuel combustion or biogenic emissions (including biomass burning). In Asian air masses, VOCs that are mainly from fossil fuel combustion sources were most closely related to WSOC variability. Biogenic VOCs did not substantially contribute to the observed variability of WSOC in Asian air masses. However, the regression model has significant variability that cannot be explained by the measured VOCs, and this is likely related to the long transport time and possible cloud scavenging or precipitation loss affecting Asian aerosols. In contrast, a multivariate regression of North American aerosols that impacts the Western United States shows that WSOC variability is driven by a combination of fossil fuel combustion and biogenic VOCs. This regression model explained a greater amount of WSOC variability $(\sim 75 \%)$.

The North American air mass data observed during this study were further refined to include only Central Valley outflow (with possible contributions from other urban regions), and compared a relatively fresh plume (aged 12 days) with a somewhat aged (2-3 days) plume that appeared to be recently advected through clouds. Multivariate regression analysis revealed that both biogenic and fossil fuel combustion VOCs were nearly equally responsible for WSOC variability in relatively fresh plumes. In contrast, biogenic VOCs appear to have a significantly stronger association with WSOC variability in a plume with stronger evidence for cloud processing ( $\sim 2 / 3$ biogenic to $\sim 1 / 3$ fossil fuel combustion). This may also have resulted in a somewhat higher $\triangle \mathrm{WSOC} / \triangle \mathrm{CO}$ regression slope for cloud-processed air masses $\left(\sim 50 \mu \mathrm{gC} \mathrm{sm}^{-3} / \mathrm{ppmv}\right)$, than what has been observed in other urban plumes ( 30 to $40 \mu \mathrm{gC} \mathrm{sm}^{-3} / \mathrm{ppmv}$ ). Cloud processing of biogenic VOCs may be an important mechanism for free tropospheric WSOC (SOA) formation, explaining enhanced WSOC concentrations above $\sim 2 \mathrm{~km}$ altitude in this and other studies.

Acknowledgements. The authors acknowledge the invaluable assistance of the C130 aircraft support team from National Center for Atmospheric Research, and from NASA Earth Science Support Office. This work was funded by NASA under contract NNG06GA68G

Edited by: H. Singh

\section{References}

Altieri, K. E., Carlton, A. G., Lim, H. J., Turpin, B. J., and Seitzinger, S. P.: Evidence for oligomer formation in clouds: Reactions of isoprene oxidation products, Environ. Sci. Technol., 40, 4956-4960, 2006.

Apel, E. C., Hills, A. J., Lueb, R., Zindel, S., Eisele, S., and Riemer, D. D.: A fast-GC/MS system to measure $C_{2}$ to $C_{4}$ carbonyls and methanol aboard aircraft, J. Geophys. Res., 108, 15-11, doi:10.1029/2002JD003199, 2003.

Baltensperger, U., Kalberer, M., Dommen, J., Paulsen, D., Alfarra, M. R., Coe, H., Fisseha, R., Gascho, A., Gysel, M., Nyeki, S., Sax, M., Steinbacher, M., Prevot, A. S. H., Sjogren, S., Weingartner, E., and Zenobi, R.: Secondary organic aerosols from anthropogenic and biogenic precursors, Faraday Discuss., 130, 265-278, 2005.

Bertschi, I. T. and Jaffe, D. A.: Long-range transport of ozone, carbon monoxide, and aerosols to the NE Pacific troposphere during the summer of 2003: Observations of smoke plumes from Asian boreal fires, J. Geophys. Res.-Atmos., 110, D05303, doi:10.1029/2004JD005135, 2005.

Brock, C. A., Hudson, P. K., Lovejoy, E. R., Sullivan, A., Nowak, J. B., Huey, L. G., Cooper, O. R., Cziczo, D. J., de Gouw, J., Fehsenfeld, F. C., Holloway, J. S., Hubler, G., Lafleur, B. G., Murphy, D. M., Neuman, J. A., Nicks, D. K., Orsini, D. A., Parrish, D. D., Ryerson, T. B., Tanner, D. J., Warneke, C., Weber, R. J., and Wilson, J. C.: Particle characteristics following cloud-modified transport from Asia to North America, J. Geophys. Res., 109, 1-18, doi:10.1029/2003JD004198, 2004.

Brock, C. A., Sullivan, A. P., Peltier, R. E., Weber, R. J., Wollny, A., de Gouw, J. A., Middlebrook, A. M., Atlas, E. L., Stohl, A., Trainer, M. K., Cooper, O. R., Fehsenfeld, F. C., Frost, G. J., Holloway, J. S., Hübler, G., Neuman, J. A., Ryerson, T. B., Warneke, C., and Wilson, J. C.: Sources of Particulate Matter in the Northeastern United States: 2. Evolution of Chemical and Microphysical Properties, J. Geophys. Res., accepted 2007.

Carlton, A. G., Turpin, B. J., Lim, H. J., Altieri, K. E., and Seitzinger, S.: Link between isoprene and secondary organic aerosol (SOA): Pyruvic acid oxidation yields low volatility organic acids in clouds, Geophys. Res. Lett., 33, L06822, doi:10.1029/2005GL025374, 2006.

de Gouw, J., Warneke, C., Karl, T., Eerdekens, G., van der Veen, C., and Fall, R.: Sensitivity and specificity of atmospheric trace gas detection by proton-transfer-reaction mass spectrometry, Int. J. Mass Spectrom., 223, 365-382, 2003.

de Gouw, J. A., Cooper, O. R., Warneke, C., Hudson, P. K., Fehsenfeld, F. C., Holloway, J. S., Hubler, G., Nicks, D. K., Jr., Nowak, J. B., Parrish, D. D., Ryerson, T. B., Atlas, E. L., Donnelly, S. G., Schauffler, S. M., Stroud, V., Johnson, K., Carmichael, G. R., and Streets, D. G.: Chemical composition of air masses transported from Asia to the U.S. West Coast during ITCT 2K2: fossil fuel combustion versus biomass-burning signatures, J. Geophys. Res., 109, D23S20, doi:10.1029/2003JD004202, 2004.

de Gouw, J. A., Middlebrook, A. M., Warneke, C., Goldan, P. D., Kuster, W. C., Roberts, J. M., Fehsenfeld, F. C., Worsnop, D. R., Canagaratna, M. R., Pszenny, A. A. P., Keene, W. C., Marchewka, M., Bertman, S. B., and Bates, T. S.: Budget of organic carbon in a polluted atmosphere: Results from the New England Air Quality Study in 2002, J. Geophys. Res., 110, 22, D16305, doi:10.1029/2004JD005623, 2005. 
de Gouw, J. A., Brock, C. A., Atlas, E. L., Bates, T. S., Fehsenfeld, F. C., Goldan, P. D., Holloway, J. S., Kuster, W. C., Lerner, B. M., Matthew, B. M., A.M. Middlebrook1, Onasch, T. B., Peltier, R. E., Quinn, P. K., Senff, C. J., Stohl, A., Sullivan, A. P., Trainer, M., Warneke, C., Weber, R. J., and Williams, E. J.: Sources of Particulate Matter in the Northeastern United States: 1. Direct Emissions and Secondary Formation of Organic Matter in Urban Plumes, J. Geophys. Res., accepted, 2007.

Decesari, S., Facchini, M. C., Matta, E., Lettini, F., Mircea, M., Fuzzi, S., Tagliavini, E., and Putaud, J. P.: Chemical features and seasonal variation of fine aerosol water-soluble organic compounds in the Po Valley, Italy, Atmos. Environ., 35, 3691-3699, 2001.

Eatough, D. J., Obeidi, F., Pang, Y., Ding, Y., Eatough, N. L., and Wilson, W. E.: Integrated and real-time diffusion denuder sampler for $\mathrm{PM}_{2.5}$, Atmos. Environ., 33, 2835-2844, 1999.

Fitzgerald, J. W.: Marine Aerosols - a Review, Atmos. Environ., 25, 533-545, 1991.

Frost, G. J., McKeen, S. A., Trainer, M., Ryerson, T. B., Neuman, J. A., Roberts, J. M., Swanson, A., Holloway, J. S., Sueper, D. T., Fortin, T., Parrish, D. D., Fehsenfeld, F. C., Flocke, F., Peckham, S. E., Grell, G. A., Kowal, D., Cartwright, J., Auerbach, N., and Habermann, T.: Effects of changing power plant NOx emissions on ozone in the eastern United States: Proof of concept, J. Geophys. Res.-Atmos., 111, D12306, doi:2005JD006354, 2006.

Guenther, A., Hewitt, C. N., Erickson, D., Fall, R., Geron, C., Graedel, T., Harley, P., Klinger, L., Lerdau, M., McKay, W. A., Pierce, T., Scholes, B., Steinbrecher, R., Tallamraju, R., Taylor, J., and Zimmerman, P.: A Global-Model of Natural Volatile Organic-Compound Emissions, J. Geophy. Res.-Atmos., 100, 8873-8892, doi:10.1029/94JD02950, 1995.

Hartz, K. E. H., Rosenorn, T., Ferchak, S. R., Raymond, T. M., Bilde, M., Donahue, N. M., and Pandis, S. N.: Cloud condensation nuclei activation of monoterpene and sesquiterpene secondary organic aerosol, J. Geophys. Res.-Atmos., 110, D14208, doi:10.1029/2004JD005754, 2005.

Hastings, W. P., Koehler, C. A., Bailey, E. L., and De Haan, D. O.: Secondary organic aerosol formation by glyoxal hydration and oligomer formation: Humidity effects and equilibrium shifts during analysis, Environ. Sci. Technol., 39, 8728-8735, 2005.

Heald, C. L., Jacob, D. J., Park, R. J., Russell, L. M., Huebert, B. J., Seinfeld, J. H., Liao, H., and Weber, R. J.: A large organic aerosol source in the free troposphere missing from current models, Geophys. Res. Lett., 32(4), L18809, doi:10.1029/2005GL023831, 2005.

Heald, C. L., Jacob, D. J., Turquety, S., Hudman, R. C., Weber, R. J., Sullivan, A. P., Peltier, R. E., Atlas, E. L., de Gouw, J. A., Warneke, C., Holloway, J. S., Neuman, J. A., Flocke, F. M., and Seinfeld, J. H.: Concentrations and sources of organic carbon aerosols in the free troposphere over North America, J. Geophys. Res., 111, D23S47, doi:10.1029/2006JD007705, 2006.

Heikes, B. G., Chang, W. N., Pilson, M. E. Q., Swift, E., Singh, H. B., Guenther, A., Jacob, D. J., Field, B. D., Fall, R., Riemer, D., and Brand, L.: Atmospheric methanol budget and ocean implication, Global Biogeochem. Cy., 16, 1133, doi:10.1029/2002GB001895, 2002.

Hopke, P. K., Paatero, P., Jia, H., Ross, R. T., and Harshman, R. A.: Three-way (PARAFAC) factor analysis: examination and comparison of alternative computational methods as applied to ill-conditioned data, Chemometr. Intell. Lab., 43, 25-42, 1998.

Hopke, P. K., Ramadan, Z., Paatero, P., Norris, G. A., Landis, M. S., Williams, R. W., and Lewis, C. W.: Receptor modeling of ambient and personal exposure samples: 1998 Baltimore Particulate Matter Epidemiology-Exposure Study, Atmos. Environ., 37, 3289-3302, 2003.

Huang, X. F., Yu, J. Z., He, L. Y., and Yuan, Z. B.: Watersoluble organic carbon and oxalate in aerosols at a coastal urban site in China: Size distribution characteristics, sources, and formation mechanisms, J. Geophys. Res.-Atmos., 111, D22212, doi:10.1029/2006JD007408, 2006.

Huang, X. F. and Yu, J. Z.: Is vehicle exhaust a significant primary source of oxalic acid in ambient aerosols?, Geophys. Res. Lett., 34, L02808, doi:10.1029/2006GL028457, 2007.

Huebert, B., Bertram, T., Kline, J., Howell, S., Eatough, D., and Blomquist, B.: Measurements of organic and elemental carbon in Asian outflow during ACE-Asia from the NSF/NCAR C-130, J. Geophys. Res.-Atmos., 109, D19S11, doi:10.1029/2004JD004700, 2004a.

Huebert, B. J., Bates, T., Russell, P. B., Shi, G. Y., Kim, Y. J., Kawamura, K., Carmichael, G., and Nakajima, T.: An overview of ACE-Asia: Strategies for quantifying the relationships between Asian aerosols and their climatic impacts, J. Geophys Res.-Atmos., 108(D23), doi:10.1029/2003JD003550, 2003.

Huebert, B. J., Howell, S. G., Covert, D., Bertram, T., Clarke, A., Anderson, J. R., Lafleur, B. G., Seebaugh, W. R., Wilson, J. C., Gesler, D., Blomquist, B., and Fox, J.: PELTI: Measuring the passing efficiency of an airborne low turbulence aerosol inlet, Aerosol Sci. Tech., 38, 803-826, 2004b.

Jacob, D. J., Field, B. D., Jin, E. M., Bey, I., Li, Q. B., Logan, J. A., Yantosca, R. M., and Singh, H. B.: Atmospheric budget of acetone, Journal of Geophys. Res.-Atmos., 107(D10), doi:10.1029/2001JD000694, 2002.

Jacob, D. J., Crawford, J. H., Kleb, M. M., Connors, V. S., Bendura, R. J., Raper, J. L., Sachse, G. W., Gille, J. C., Emmons, L., and Heald, C. L.: Transport and Chemical Evolution over the Pacific (TRACE-P) aircraft mission: Design, execution, and first results, J. Geophys. Res.-Atmos., 108, 1-19, doi:10.1029/2002JD003276, 2003.

Jacob, D. J., Field, B. D., Li, Q. B., Blake, D. R., de Gouw, J., Warneke, C., Hansel, A., Wisthaler, A., Singh, H. B., and Guenther, A.: Global budget of methanol: Constraints from atmospheric observations, J. Geophys. Res.-Atmos., 110, D08303, doi:10.1029/2004JD005172, 2005.

Jacobson, M. C., Hansson, H.-C., Noone, K. J., and Charlson, R. J.: Organic atmospheric aerosols: review and state of the science, Rev. Geophys., 38, 267-294, 2000.

Jaffe, D., Anderson, T., Covert, D., Kotchenruther, R., Trost, B., Danielson, J., Simpson, W., Berntsen, T., Karlsdottir, S., Blake, D., Harris, J., Carmichael, G., and Uno, I.: Transport of Asian air pollution to North America, Geophys. Res. Lett., 26, 711714, doi:10.1029/1999GL900100, 1999.

Jaffe, D., Tamura, S., and Harris, J.: Seasonal cycle and composition of background fine particles along the west coast of the US, Atmos. Environ., 39, 297-306, 2005.

Jaffrezo, J. L., Aymoz, G., Delaval, C., and Cozic, J.: Seasonal variations of the water soluble organic carbon mass fraction of aerosol in two valleys of the French Alps, Atmos. Chem. Phys., 5, 2809-2821, 2005, 
http://www.atmos-chem-phys.net/5/2809/2005/.

Johnson, D., Utembe, S. R., and Jenkin, M. E.: Simulating the detailed chemical composition of secondary organic aerosol formed on a regional scale during the TORCH 2003 campaign in the southern UK, Atmos. Chem. Phys., 6, 419-431, 2006,

http://www.atmos-chem-phys.net/6/419/2006/.

Kim, E. and Hopke, P. K.: Comparison between sample-species specific uncertainties and estimated uncertainties for the source apportionment of the speciation trends network data, Atmos. Environ., 41, 567-575, 2007.

Kim, J. O. and Ferree, G. D.: Standardization in Causal-Analysis, Sociol. Method. Res., 10, 187-210, 1981.

Lee, Y. N., Weber, R., Ma, Y., Orsini, D., Maxwell-Meier, K., Blake, D., Meinardi, S., Sachse, G., Harward, C., Chen, T. Y., Thornton, D., Tu, F. H., and Bandy, A.: Airborne measurement of inorganic ionic components of fine aerosol particles using the particle-into-liquid sampler coupled to ion chromatography technique during ACE-Asia and TRACE-P, J. Geophys. Res., 108, 14-11, doi:10.1029/2002JD003265, 2003.

Lewis, A. C., Hopkins, J. R., Carpenter, L. J., Stanton, J., Read, K. A., and Pilling, M. J.: Sources and sinks of acetone, methanol, and acetaldehyde in North Atlantic marine air, Atmos. Chem. Phys., 5, 1963-1974, 2005,

http://www.atmos-chem-phys.net/5/1963/2005/.

Lim, H. J., Carlton, A. G., and Turpin, B. J.: Isoprene forms secondary organic aerosol through cloud processing: Model simulations, Environ. Sci. Tech., 39, 4441-4446, 2005.

Lindinger, W., Hansel, A., and Jordan, A.: On-line monitoring of volatile organic compounds at pptv levels by means of protontransfer-reaction mass spectrometry (PTR-MS) - Medical applications, food control and environmental research, Int. J. Mass Spectrom., 173, 191-241, 1998.

Ma, Y., Weber, R. J., Lee, Y. N., Orsini, D. A., Maxwell-Meier, K., Thornton, D. C., Bandy, A. R., Clarke, A. D., Blake, D. R., Sachse, G. W., Fuelberg, H. E., Kiley, C. M., Woo, J. H., Streets, D. G., and Carmichael, G. R.: Characteristics and influence of biosmoke on the fine-particle ionic composition measured in Asian outflow during the Transport and Chemical Evolution Over the Pacific (TRACE-P) experiment, J. Geophys. Res., 108, GTE 37-31-GTE 37-16, doi:10.1029/2002JD003128, 2003.

Maria, S. F., Russell, L. M., Turpin, B. J., Porcja, R. J., Campos, T. L., Weber, R. J., and Huebert, B. J.: Source signatures of carbon monoxide and organic functional groups in Asian Pacific Regional Aerosol Characterization Experiment (ACE-Asia) submicron aerosol types, J. Geophys. Res., 108, ACE 5-1-ACE 5-14, doi:10.1029/2003JD003703, 2003.

Marple, V. A., Rubow, K. I., and Behm, S. M.: Microorifice uniform deposit impactor (MOUDI): description, calibration, and use, Aerosol Sci. Tech., 14, 434-446, 1991.

Matsunaga, S. N., Wiedinmyer, C., Guenther, A. B., Orlando, J. J., Karl, T., Toohey, D. W., Greenberg, J. P., and Kajii, Y.: Isoprene oxidation products are a significant atmospheric aerosol component, Atmos. Chem. Phys. Discuss., 5, 11 143-11 156, 2005.

Millet, D. B., Goldstein, A. H., Allan, J. D., Bates, T. S., Boudries, H., Bower, K. N., Coe, H., Ma, Y. L., McKay, M., Quinn, P. K., Sullivan, A., Weber, R. J., and Worsnop, D. R.: Volatile organic compound measurements at Trinidad Head, California, during ITCT 2K2: Analysis of sources, atmospheric composition, and aerosol residence times, J. Geophys. Res.-Atmos., 109, D23S16,
doi:10.1029/2003JD004026, 2004.

Millet, D. B., Donahue, N. M., Pandis, S. N., Polidori, A., Stanier, C. O., Turpin, B. J., and Goldstein, A. H.: Atmospheric volatile organic compound measurements during the Pittsburgh Air Quality Study: Results, interpretation, and quantification of primary and secondary contributions, J. Geophys. Res.-Atmos., 110, D07S07, doi:10.1029/2004JD004601, 2005.

Millet, D. B., Goldstein, A. H., Holzinger, R., Williams, B. J., Allan, J. D., Jimenez, J. L., Worsnop, D. R., Roberts, J. M., White, A. B., Hudman, R. C., Bertschi, I. T., and Stohl, A.: Chemical characteristics of North American surface layer outflow: Insights from Chebogue Point, Nova Scotia, J. Geophys. Res.-Atmos., 111(D23), doi:10.1029/2006JD007287, 2006.

Murphy, D. M., Cziczo, D. J., Froyd, K. D., Hudson, P. K., Matthew, B. M., Middlebrook, A. M., Peltier, R. E., Sullivan, A., Thomson, D. S., and Weber, R. J.: Single-particle mass spectrometry of tropospheric aerosol particles, J. Geophys. Res.-Atmos., 111, D23S32, doi:10.1029/2006JD007340 2006.

Na, K., Song, C., and Cocker, D. R.: Formation of secondary organic aerosol from the reaction of styrene with ozone in the presence and absence of ammonia and water, Atmos. Environ., 40, 1889-1900, 2006.

Nowak, J. B., Huey, L. G., Russell, A. G., Tian, D., Neuman, J. A., Orsini, D., Sjostedt, S. J., Sullivan, A. P., Tanner, D. J., Weber, R. J., Nenes, A., Edgerton, E., and Fehsenfeld, F. C.: Analysis of urban gas phase ammonia measurements from the 2002 Atlanta Aerosol Nucleation and Real-Time Characterization Experiment (ANARChE), J. Geophys. Res.-Atmos., 111, D17308, doi:10.1029/2006JD007113, 2006.

Olivier, J. G. J. and Berdowski, J. J. M.: Global emissions sources and sinks, The Climate System, edited by: Berdowski, J., Guicherit, R. and Heij, B. J., A. A. Balkema Publishers/Swets \& Zeitlinger Publishers, Lisse, The Netherlands, 33-78, 2001.

Orsini, D. A., Ma, Y., Sullivan, A., Sierau, B., Baumann, K., and Weber, R. J.: Refinements to the particle-into-liquid sampler (PILS) for ground and airborne measurements of water soluble aerosol composition, Atmos. Environ., 37, 1243-1259, 2003.

Park, R. J., Jacob, D. J., Chin, M., and Martin, R. V.: Sources of carbonaceous aerosols over the United States and implications for natural visibility, J. Geophys. Res., 108, AAC 5-1-AAC 514, doi:10.1029/2002JD003190, 2003.

Peltier, R. E., Sullivan, A. P., Weber, R. J., Brock, C. A., Wollny, A. G., Holloway, J. S., De Gouw, J. A., and Warneke, C.: Fine aerosol bulk composition measured on WP-3D research aircraft in vicinity of the Northeastern United States - results from NEAQS, Atmos. Chem. Phys., 7, 3231-3247, 2007a, http://www.atmos-chem-phys.net/7/3231/2007/.

Peltier, R. E., Weber, R. J., and Sullivan, A. P.: Investigating a Method for Online OC Detection with a ParticleInto-Liquid Sampler, Aerosol Sci. Tech., 41, 1117-1127, doi:10.1080/02786820701777465, 2007b.

Pun, B. K., Seigneur, C., Grosjean, D., and Saxena, P.: Gasphase formation of water-soluble organic compounds in the atmosphere: A retrosynthetic analysis, J. Atmos. Chem., 35, 199223, 1999.

Pun, B. K., Griffin, R. J., Seigneur, C., and Seinfeld, J. H.: Secondary organic aerosol -2 . Thermodynamic model for gas/particle partitioning of molecular constituents, J. Geophys. Res.-Atmos., 107(D17), doi:10.1029/2001JD000542, 2002. 
Quinn, P. K., Bates, T. S., Coffman, D., Onasch, T. B., Worsnop, D., Baynard, T., de Gouw, J. A., Goldan, P. D., Kuster, W. C., Williams, E., Roberts, J. M., Lerner, B., Stohl, A., Pettersson, A., and Lovejoy, E. R.: Impacts of sources and aging on submicrometer aerosol properties in the marine boundary layer across the Gulf of Maine, J. Geophys. Res.-Atmos., 111, D23S36, doi:10.1029/2006JD007582, 2006.

Reiner, T., Sprung, D., Jost, C., Gabriel, R., Mayol-Bracero, O. L., Andreae, M. O., Campos, T. L., and Shetter, R. E.: Chemical characterization of pollution layers over the tropical Indian Ocean: Signatures of emissions from biomass and fossil fuel burning, J. Geophys. Res.-Atmos., 106, 28 497-28 510, doi:10.1029/2000JD900695, 2001.

Rogge, W. F., Mazurek, M. A., Hildemann, L. M., Cass, G. R., and Simoneit, B. R. T.: Quantification of urban organic aerosols at a molecular level: Identification, abundance and seasonal variation, Atmos. Environ., 27A, 1309-1330, 1993.

Seinfeld, J. H. and Pankow, J. F.: Organic atmospheric particulate material, Annu. Rev. Phys. Chem., 54, 121-140, 2003.

Shim, C. S., Wang, Y. H., Singh, H. B., Blake, D. R., and Guenther, A. B.: Source characteristics of oxygenated volatile organic compounds and hydrogen cyanide, J. Geophys. Res.-Atmos., 112, D10305, doi:10.1029/2006JD007543, 2007.

Singh, H. B., Salas, L. J., Chatfield, R. B., Czech, E., Fried, A., Walega, J., Evans, M. J., Field, B. D., Jacob, D. J., Blake, D., Heikes, B., Talbot, R., Sachse, G., Crawford, J. H., Avery, M. A., Sandholm, S., and Fuelberg, H.: Analysis of the atmospheric distribution, sources, and sinks of oxygenated volatile organic chemicals based on measurements over the Pacific during TRACE-P, J. Geophys. Res.-Atmos., 109(D15), doi:10.1029/2003JD003883, 2004.

Sorooshian, A., Varutbangkul, V., Brechtel, F. J., Ervens, B., Feingold, G., Bahreini, R., Murphy, S. M., Holloway, J. S., Atlas, E. L., Buzorius, G., Jonsson, H., Flagan, R. C., and Seinfeld, J. H.: Oxalic acid in clear and cloudy atmospheres: Analysis of data from International Consortium for Atmospheric Research on Transport and Transformation 2004, J. Geophys. Res.Atmos., 111(D23), doi:10.1029/2005JD006880, 2006.

Sorooshian, A., Lu, M. L., Brechtel, F. J., Jonsson, H., Feingold, G., Flagan, R. C., and Seinfeld, J. H.: On the source of organic acid aerosol layers above clouds, Environ. Sci. Technol., 41, 46474654, 2007.

Spaulding, R. S., Schade, G. W., Goldstein, A. H., and Charles, M. J.: Characterization of secondary atmospheric photooxidation products: Evidence for biogenic and anthropogenic sources, J. Geophys. Res.-Atmos., 108(D8), doi:10.1029/2002JD002478, 2003.

Staudinger, J., and Roberts, P. V.: A critical review of Henry's law constants for environmental applications, Crit. Rev. Env. Sci. Tec., 26, 205-297, 1996.

Stohl, A., Hittenberger, M., and Wotawa, G.: Validation of the Lagrangian particle dispersion model FLEXPART against largescale tracer experiment data, Atmos. Environ., 32, 4245-4264, 1998.

Stohl, A., Forster, C., Frank, A., Seibert, P., and Wotawa, G.: Technical note: The Lagrangian particle dispersion model FLEXPART version 6.2, Atmos. Chem. Phys., 5, 2461-2474, 2005, http://www.atmos-chem-phys.net/5/2461/2005/.

Streets, D. G. and Waldhoff, S. T.: Present and future emissions of air pollutants in China: SO2, NOx, and CO, Atmos. Environ., 34, 363-374, 2000.

Streets, D. G., Bond, T. C., Carmichael, G. R., Fernandes, S. D., Fu, Q., He, D., Klimont, Z., Nelson, S. M., Tsai, N. Y., Wang, M. Q., Woo, J. H., and Yarber, K. F.: An inventory of gaseous and primary aerosol emissions in Asia in the year 2000, J. Geophys. Res.-Atmos., 108(D21), doi:10.1029/2002JD003093, 2003.

Streets, D. G.: Dissecting future aerosol emissions: Warming tendencies and mitigation opportunities, Clim. Change, 81, 313330, 2007.

Sullivan, A. P., Peltier, R. E., Brock, C. A., de Gouw, J. A., Holloway, J. S., Warneke, C., Wollny, A. G., and Weber, R. J.: Airborne measurements of carbonaceous aerosol soluble in water over northeastern United States: Method development and an investigation into water-soluble organic carbon sources, J. Geophys. Res., 111, 1-14, doi:10.1029/2005JD006485, 2006.

Sullivan, A. P. and Weber, R. J.: Chemical characterization of the ambient organic aerosol soluble in water. 1. Isolation of hydrophobic and hydrophilic fractions with a XAD-8 resin, J. Geophys. Res., 111, D05314, doi:10.1029/2005JD006485, 2006.

Tsigaridis, K. and Kanakidou, M.: Global modelling of secondary organic aerosol in the troposphere: a sensitivity analysis, Atmos. Chem. Phys., 3, 1849-1869, 2003,

http://www.atmos-chem-phys.net/3/1849/2003/.

Turpin, B. J., Saxena, P., and Andrews, E.: Measuring and simulating particulate organics in the atmosphere: problems and prospects, Atmos. Environ., 34, 2983-3013, 2000.

Varutbangkul, V., Brechtel, F. J., Bahreini, R., Ng, N. L., Keywood, M. D., Kroll, J. H., Flagan, R. C., Seinfeld, J. H., Lee, A., and Goldstein, A. H.: Hygroscopicity of secondary organic aerosols formed by oxidation of cycloalkenes, monoterpenes, sesquiterpenes, and related compounds, Atmos. Chem. Phys., 6, 23672388, 2006,

http://www.atmos-chem-phys.net/6/2367/2006/.

Volkamer, R., Jimenez, J. L., San Martini, F., Dzepina, K., Zhang, Q., Salcedo, D., Molina, L. T., Worsnop, D. R., and Molina, M. J.: Secondary organic aerosol formation from anthropogenic air pollution: Rapid and higher than expected, Geophys. Res. Lett., 33, L17811, doi:10.1029/2006GL026899, 2006.

Wang, Y., Liu, S. C., Anderson, B. E., Kondo, Y., Gregory, G. L., Sachse, G. W., Vay, S. A., Blake, R., Singh, H. B., and Thompson, A. M.: Evidence of convection as a major source of condensation nuclei in the northern midlatitude upper troposphere, Geophys. Res. Lett., 27, 369-372, doi:10.1029/1999GL010930, 2000.

Weber, R. J., Orsini, D., Daun, Y., Lee, Y. N., Klotz, P. J., and Brechtel, F.: A particle-into-liquid collector for rapid measurement of aerosol bulk chemical composition, Aerosol Sci. Tech., 35, 718-727, 2001.

Weber, R. J., Sullivan, A. P., Peltier, R. E., Russell, A. G., Yan, B., Chen, Y., Zheng, M., De Gouw, J. A., Warneke, C., Brock, C. A., Holloway, J. S., Atlas, E. L., and Edgerton, E.: A Study of Secondary Organic Aerosol Formation in the AnthropogenicInfluenced Southeastern USA., J. Geophys. Res., 112, D13302, doi:10.1029/2007JD008408, 2007.

Yaws, C. L.: Thermodynamic and physical property data, vi, Gulf Publishing, Houston, TX, 217 pp., 1992.

Yu, J. Z., Jeffries, H. E., and Lelacheur, R. M.: Identifying Airborne Carbonyl-Compounds in Isoprene Atmospheric Photooxidation 
Products by Their Pfbha Oximes Using Gas-Chromatography Ion-Trap Mass-Spectrometry, Environ. Sci. Technol., 29, 19231932, 1995.

Zappoli, S., Andracchio, A., Fuzzi, S., Facchini, M. C., Gelencser, A., Kiss, G., Krivacsy, Z., Molnar, A., Meszaros, E., Hansson, H. C., Rosman, K., and Zebuhr, Y.: Inorganic, organic and macromolecular components of fine aerosol in different areas of Europe in relation to their water solubility, Atmos. Environ., 33, 27332743, 1999.

Zhang, Q., Jimenez, J. L., Canagaratna, M. R., Allan, J. D., Coe, H., Ulbrich, I., Alfarra, M. R., Takami, A., Middlebrook, A. M., Sun, Y. L., Dzepina, K., Dunlea, E., Docherty, K., DeCarlo, P. F., Salcedo, D., Onasch, T., Jayne, J. T., Miyoshi, T., Shimono, A., Hatakeyama, S., Takegawa, N., Kondo, Y., Schneider, J., Drewnick, F., Borrmann, S., Weimer, S., Demerjian, K., Williams, P., Bower, K., Bahreini, R., Cottrell, L., Griffin, R. J., Rautiainen, J., Sun, J. Y., Zhang, Y. M., and Worsnop, D. R.: Ubiquity and dominance of oxygenated species in organic aerosols in anthropogenically-influenced Northern Hemisphere midlatitudes, Geophys. Res. Lett., 34, L13801, doi:10.1029/2007GL029979 2007. 